\title{
Taking Ethics Codes Seriously: Broad Ethics Provisions and Unenumerated Ethical Obligations in a Comparative Hermeneutic Framework
}

Samuel J. Levine

Touro Law Center, slevine@tourolaw.edu

Follow this and additional works at: https://digitalcommons.tourolaw.edu/scholarlyworks

Part of the Comparative and Foreign Law Commons, and the Legal Ethics and Professional Responsibility Commons

\section{Recommended Citation}

77 Tulane L. Rev. 527 (2003).

This Article is brought to you for free and open access by the Faculty Scholarship at Digital Commons @ Touro Law Center. It has been accepted for inclusion in Scholarly Works by an authorized administrator of Digital Commons @ Touro Law Center. For more information, please contact Iross@tourolaw.edu. 


\title{
TULANE \\ LAW REVIEW
}

VOL. 77

FEBRUARY 2003

No. 3

\section{Taking Ethics Codes Seriously: Broad Ethics Provisions and Unenumerated Ethical Obligations in a Comparative Hermeneutic Framework}

\author{
Samuel J. Levine*
}

\begin{abstract}
Ethics scholars have documented the increasingly legislative form of twentieth-century ethics regulations, culminating in the enactment and widespread adoption of the Model Rules of Professional Conduct. Nevertheless, pointing to the presence of broad ethics provisions, a number of leading scholars have questioned the extent to which ethics codes can accurately be conceptualized as a form of legislation. Responding to these critiques, this Article aims to take seriously both the legislative form of ethics codes and their interpretation. Toward that aim, the Article looks to interpretive methodologies employed in American constitutional law and Jewish law to provide both descriptive and normative models for the analysis of ethics codes.

Focusing on three broad provisions that have been the target of criticism, the Article examines three related yet conceptually distinct interpretive methodologies that have been employed to derive unenumerated constitutional rights and unenumerated biblical obligations, then proceeds to apply these methodologies to the interpretation of the three broad ethics provisions. The Article thus presents both on a descriptive level, through an analysis of court opinions, and on a normative level, a comparative framework for interpreting broad ethics provisions to derive and identify unemumerated ethical obligations. The Article concludes with a call for scholars and courts that have criticized broad ethics provisions to reexamine their approach and consider the viability of adopting the interpretive methods presented.
\end{abstract}

I. INTRODUCTION

II. ETHICS CODES AS LEGISLATION 530

* Associate Professor of Law, Pepperdine University School of Law. B.A. \& Ordination, Yeshiva University; J.D., Fordham University; LL.M., Columbia University. I thank Randy Lee, Russ Pearce, and Tom Shaffer for helpful conversations and Fraida Liba, Yehudah Tzvi, and Aryeh Shalom for their encouragement. 
III. THE NEED FOR AND FUNCTION OF GENERAL RULES IN ETHICS CODES, CONSTITUTIONAL LAW, AND JEWISH LAW .........538

IV. DERIVING AND IDENTIFYING UNENUMERATED ETHICAL OBLIGATIONS: AN EXERCISE IN COMPARATIVE HERMENEUTICS

A. Interpretive Methodologies Employed in the Derivation of Unenumerated Constitutional Rights and Unenumerated Biblical Obligations... 546

B. Applying the Interpretive Methodologies: Deriving and Identifying Unenumerated Ethical Obligations.

1. DR 1-102(A)(6): "Conduct that Adversely

Reflects on [the Lawyer's] Fitness to Practice Law".

2. DR 1-102(A)(5); Rule 8.4(d): "Conduct That Is Prejudicial to the Administration of Justice".........558

3. Canon 9: "Avoid[ing] Even the Appearance of Professional Impropriety".

V. CONCLUSION

\section{INTRODUCTION}

In an influential 1991 law review article, Professor Geoffrey Hazard described the "legalization" of the rules governing the legal profession.' As Professor Hazard observed, ethics codes have evolved from the status of "fraternal norms issuing from an autonomous professional society" to become "a body of judicially enforced regulations.". In Hazard's words, ethics rules have developed into "a code of public law enforced by formal adjudicative disciplinary process." ${ }^{3}$ Building on Hazard's work, Professor Fred Zacharias has noted that "[o]ver time, the professional codes governing lawyer behavior have become statutory in form."4

Yet, pointing to the presence of broad ethics provisions, leading scholars have questioned the extent to which ethics codes can

1. Geoffrey C. Hazard, Jr., The Future of Legal Ethics, 100 YALE L.J. 1239, 1241-42 (1991)

2. Id. at 1249.

3. Id. at 124 l; cf. Charles W. Wolfram, MOdern Legal ETHICS 67 (1986) (stating that "the enforcement of the provisions of lawyer codes in lawyer discipline and other proceedings demonstrates clearly that the codes are legal prescriptions in every conventional sense").

4. Fred C. Zacharias, Specificity in Professional Responsibility Codes: Theory, Practice, and the Paradigm of Prosecutorial Ethics, 69 Notre DAME L. REv. 223, 223 (1993). 
accurately be conceptualized as a form of legislation. In his landmark Modern Legal Ethics, Professor Charles Wolfram faulted both the Model Code of Professional Responsibility and the Model Rules of Professional Conduct for "contain[ing] vague provisions." As Professor Richard Painter more recently put it, although "codes have migrated away from broad standards and toward clearly defined rules[,] . . . many standards still prevail. ${ }^{.06}$

Responding to these critiques, this Article aims to take seriously both the legislative form of ethics codes and their interpretation. Toward that aim, the Article looks to interpretive methodologies employed in American constitutional law and Jewish law to provide both descriptive and normative models for the analysis of ethics codes. Specifically, the Article focuses on the hermeneutic practice, applicable to all three of the legislative systems examined, of deriving unenumerated laws through the interpretation of broad provisions.

Part I of the Article documents the increasingly legislative form of ethics regulations, resulting first in the promulgation of the Model Code and, later, in the appearance of the Model Rules. At the same time, this Part addresses the criticism that Professor Wolfram and other scholars have leveled against broad ethics provisions, focusing in particular on three provisions that have been the target of such criticism: (1) DR 1-102(A)(6) of the Model Code, which prohibits conduct that adversely reflects on the lawyer's fitness to practice law; (2) DR 1-102(A)(5) of the Model Code, which was later adopted as Model Rule 8.4(d), which prohibits conduct that is prejudicial to the administration of justice; and (3) Canon 9 of the Model Code, which instructs lawyers to avoid even the appearance of impropriety.

In response to the critics, Part II of the Article introduces a comparative framework for examining the need for and function of broad principles within the legislative structure of ethics codes, the United States Constitution, and the Torah. Part III then presents three related, yet conceptually distinct, interpretive methodologies that have been employed to derive unenumerated constitutional rights and unenumerated biblical obligations. Finally, this Part proceeds to apply these methodologies to the interpretation of the three broad ethics provisions noted above, demonstrating both on a descriptive level, through an analysis of court opinions, and on a normative level, a comparative framework for interpreting broad ethics provisions to

5. WOLFRAM, supra note 3 , at 87.

6. Richard W. Painter, Rules Lawyers Play By, 76 N.Y.U. L. REv. 665, 668 (2001). 
derive and identify unenumerated ethical obligations. The Article concludes with a call for scholars and courts that have criticized these broad ethics provisions to reexamine their approach and consider the viability of adopting the interpretive methods presented.

\section{ETHICS CODES AS LEGISLATION}

Numerous scholars have documented the evolution of ethics rules in the twentieth century, "transforming legal ethics into positive law." The transformation began slowly, as the American Bar Association's (ABA) first attempt to establish authoritative guidelines for legal ethics, the 1908 Canons of Professional Ethics, "did not embody ...

7. See, e.g., Wolfram, supra note 3, at 53-63; Mary C. Daly, The Dichotomy Between Standards and Rules: A New Way of Understanding the Differences in Perceptions of Lawyer Codes of Conduct by U.S. and Foreign Lawyers, 32 VAND. J. TRANSNAT'L L. 1117, 1124-34 (1999); Bruce A. Green, Doe v. Grievance Committee: On the Interpretation of Ethical Rules, S5 BRoOK. L. REv. 485, 531-32 (1989); Hazard, supra note 1, at 1249-60; Painter, supra note 6, at 668-69; Tanina Rostain, Ethics Lost: Limitations of Current Approaches to Lawyer Regulation, 7I S. CAL. L. REV. 1273, 1279-80, 1288-99 (1988); Murray L. Schwartz, The Death and Regeneration of Ethics, 1980 AM. B. Found. RES. J. 953, 954-55; Maura Strassberg, Taking Ethics Seriously: Beyond Positivist Jurisprudence in Legal Ethics, 80 IOWA L. REv. 901, 905-10 (1995); Charles W. Wolfram, Toward a History of the Legalization of American Legal Ethics-I: Origins, 8 U. CHI. L. SCH. RoundTABLE 469 (2001); Charles W. Wolfram, Toward a History of the Legalization of American Legal Ethics-II: The Modern Era, 15 GEO. J. LEGAL ETHICS 205 (2002); Zacharias, supra note 4, at 225-27 \& nn.7-10.

Professor Daly's article considers the issue of specificity in ethics provisions in the broader conceptual framework of the rules/standards dichotomy. Among other reasons, the application of this framework to ethics codes is significant because it may point to another similarity in the hermeneutic methodology of legal ethics, constitutional law, and Jewish law. The place of the rules/standards dichotomy in constitutional interpretation has been clearly established. See Daly, supra, at 1118 n.1 (citing. David L. Faigman, Constitutional Adventures in Wonderland: Exploring the Debate Between Rules and Standards Through the Looking Glass of the First Amendment, 44 HASTINGS L.J. 829 (1993); Antonin Scalia, The Rule of Law as a Law of Rules, 56 U. CHI. L. REV. 1175 (1989); Kathleen M. Sullivan, The Supreme Court 1991 Term, Foreword: The Justices of Rules and Standards, 106 HaRv. L. REV. 22 (1992)). Likewise, the rules/standards dichotomy has been applied in the context of Jewish legal theory. See, e.g., Samuel J. Levine, Jewish Legal Theory and American Constitutional Theory: Some Comparisons and Contrasts, 24 HASTINGS Const. L.Q. 441, 478-501 (1997); Irene Merker Rosenberg et al., Murder by Gruma: Causation in Homicide Cases Under Jewish Law, 80 B.U. L. REV. 1017, 1038-39 (2000).

For an analysis of the role that the evolution of ethics rules has played in the "steady growth in the regulation of the legal market ... from an unregulated market to the high level of regulation we observe today," see Benjamin Hoorn Barton, Why Do We Regulate Lawyers?: An Economic Analysis of the Justifications for Entry and Conduct Regulation, 33 ARIz. ST. L.J. 429, 430 (2001).

8. Strassberg, supra note 7, at 905; see also Roger C. Cramton \& Lisa K. Udell, State Ethics Rules and Federal Prosecutors: The Controversies over the Anti-Contact and Subpoena Rules, 53 U. PITT. L. REv. 291, 300 (1992) ("Since about 1930, with accelerating speed since 1970, ethical codes have developed into law."). 
enforceable rules." Instead, the Canons consisted of wording "too vague and general to afford guidance"10 or to serve as "a basis for discipline."11

Decades later, the ABA embarked upon an effort to produce a set of ethics rules that would be "capable of enforcement" and would "facilitate more effective disciplinary action." the 1969 Model Code of Professional Responsibility. ${ }^{13}$ Significantly, in contrast to the general nature of the Canons, the Model Code includes "blackletter law"1/4 through specific Disciplinary Rules that the Code describes as "mandatory in character" and as "stat[ing] the minimum level of conduct below which no lawyer can fall without being subject to disciplinary action."'s Hazard thus refers to the Model Code as the "crucial step" in the legalization of ethics regulation, having "first embraced legally binding norms.".16

Moreover, as Professor Mary Daly has noted, the Code uses "language equally suitable for a criminal statute"17 in declaring that "[w]ithin the framework of fair trial, the Disciplinary Rules should be uniformly applied to all lawyers, regardless of the nature of their professional activities." ${ }^{318}$ Indeed, Hazard writes that the Disciplinary Rules "functioned as a statute defining the legal contours of a vocation whose practitioners were connected primarily by having been licensed to practice law."' In short, as Professor Maura Strassberg declared, through the inclusion of the Disciplinary Rules, the Model Code "essentially completed the articulation of legal ethics as positive law."20

Despite its widespread influence and its adoption by nearly every state $^{21}$ the Model Code was also widely criticized, on a number of

9. Strassberg, supra note 7, at 908.

10. WoLFRAM, supra note 3 , at 55 .

11. Strassberg, supra note 7 , at 908 .

12. Id. (quoting Walter P. Armstrong, A Century of Legal Ethics, 64 A.B.A. J. 1063 , 1069 (1978)).

13. WOLFRAM, supra note 3 , at 56 . Although the code was originally called simply the "Code of Professional Responsibility" in 1978, pursuant to a settlement of Justice Department antitrust charges, the name was changed to its current form. See Wolfram, supra note 3, at 57.

14. See Hazard, supra note 1, at 1251.

15. MODEL CODE OF PROF'L RESPONSIBILITY preliminary statement (1981).

16. Hazard, supra note 1, at 1251 .

17. Daly, supra note 7, at 1129; cf. Schwartz, supra note 7, at 957 ("Analogous to a criminal code, the Disciplinary Rules define minimum acceptable behavior.").

18. MODEL CODE OF PROF'L RESPONSIBILITY preliminary statement (footnote omitted).

19. Hazard, supra note 1 , at 1251 .

20. Strassberg, supra note 7, at 909.

21. See Wolfram, supra note 3 , at 56. 
different grounds. ${ }^{22}$. The ABA responded with yet another set of ethical standards, the 1983 Model Rules of Professional Conduct. The statutory character of the Model Rules was already evident in its drafting process, which Hazard has termed "quasi-legislative" because of the extent to which it "mirrored that of public lawmaking.".23 Professor Strassberg suggests that the very title of the Model Rules reflects the renunciation of "any intention at articulating ethics" ${ }^{\text {"24 }}$ in favor of "a code of positive law," thereby "remak[ing] the concept of legal ethics."25 Describing the structure of the Model Rules, Robert Kutak, chair of the ABA commission that drafted the Rules, explained that the "format of black-letter rules accompanied by explanatory comments ... replicates the familiar, time-tested approach of the American Law Institute's restatements of the law and modern model legislation."26 Perhaps most significantly, focusing on the "normative rhetoric" ${ }^{\prime 27}$ of the Model Rules, Hazard similarly observes that "the Rules were rendered in statutory language" and "thus implied that the normative definition of the profession could be expressed only using the medium of legally binding rules:"28

22. See id. at 60. Professor Wolfram has observed that "[i]ts critics started from different and sometimes conflicting positions." Id.; see also Daly, supra note 7, at 1130-32; Strassberg, supra note 7 , at 909.

23. Hazard, supra note 1, at. 1253. Hazard cites Professor Ted Schneyer's description of the adoption of the Model Rules as "the most sustained and democratic debate about professional ethics in the history of the American bar." Id. at 1252 n.64 (quoting Ted Schneyer, Professionalism as Bar Politics: The Making of the Model Rules of Professional Conduct, 14 LAW \& SoC. INQUIRY 677, 67,8 (1989)).

24. Strassberg, supra note 7, at 909; cf. Daly, supra note 7, at 1125 (stating that the transformation of ethics regulations in the twentieth century is "poignantly captured by the metamorphosis of their titles-from Canons to Code to Rules"). In fact, Professor Schwartz has suggested that the relationship between various forms of professional standards and their titles dates back to the nineteenth century. See Schwartz, supra note 7, at 954-55 (citing David Hoffman, Fifty Resolutions in Regard to Professional Deportment, in THE CANONS OF Professional and Judicial Ethics \& Hoffman's 50 Resolutions (C.E.H. ed., 1959) (1836); George SHARSWOOD, A COMPEND OF LECTURES ON THE AIMS AND DUTIES OF THE PROFESSION OF THE LAW (1854)).

25. Strassberg, supra note 7, at 909-10; cf. Daly, supra note 7, at 1133 (concluding that "[t]he purpose of the Model Rules was to command the conduct of lawyers, not to recommend the consideration of vague and imprecise values in ethical decisionmaking").

26. Robert J. Kutak, Evaluating the Proposed Model Rules of Professional Conduct, 1980 AM. B. Found. Res. J. 1016, 1016-17; cf. Geoffrey C. Hazard, Jr., Legal Ethics: Legal Rules and Professional Aspirations, 30 CLEV. St. L. REV. 571,574 (1981) (stating that unlike the Model Code, the "Model Rules are cast in the familiar and much more reliable form of the restatements ... provid[ing] a black letter rule and an explanatory comment" because "[t]he practicing lawyer needs and is entitled to legal rules").

27. Hazard, supra note 1, at 1253.

28. Id. at 1254; of. Daly, supra note 7, at 1132 (noting that "[t]he overwhelming majority of the Model Rules ... are cast in the imperative[,] ... even those that employ 
In addition to their legislative form; ethics regulations have evolved to acquire the status of legal authority similar to that of legislation. As Hazard explains, the ABA recognized that it required the "aid of the courts," which possess the authority to enforce such sanctions as disbarment and suspension as well as the authority to "transform[] the norms of professional conduct into binding legal rules. ${ }^{\prime 29}$ As a result, the Model Code, in Hazard's words, was not only "written like a statute" but also "propounded to the states as model legislation" and "adopted by the states as legislation."30 Likewise, in a draft of his Foreword to The Restatement of the Law Governing Lawyers, referring to ethics codes, Hazard reminded readers to "ke[ep] constantly in mind that these regulations are rules of law and not merely admonitions of the legal profession to its members.... [T] Code and the Rules, as adopted in various states, are a form of legislation with attendant authoritative significance."31 In sum, as a

permissive language are more detailed and precise than provisions in the 1908 Canons and Model Code").

29. Hazard, supra note 1, at 1250-51; cf. Green, supra note 7, at 532-33 (emphasizing that "[n]either the adoption of the Code by the ABA nor its endorsement by the Connecticut Bar Association made it enforceable against an attorney who was practicing in Connecticut," but rather that "[t]he Code took legal effect in Connecticut when, in accordance with the state bar's recommendation, the judges of the superior court approved the Code").

30. Geoffrey C. Hazard, Jr., The Legal and Ethical Position of the Code of Professional Ethics, in 5 SOCIAL ResponsibilitY: JouRNALISM, LAW, MEDICINE 5, 6 (Louis Hodges ed., 1979).

Conversely, describing the drafting of the Model Rules and addressing concerns about "expansions" of provisions found in the Model Code, Kutak emphasized the extent to which the Rules conformed to decisions of the courts, insisting that "[m]any of the expansions ... merely restate rules developed in cases." Kutak, supra note 26, at 1022; see id. at 1021-23; cf. Gary A. Munneke \& Anthony E. Davis, The Standard of Care in Legal Malpractice: Do the Model Rules of Professional Conduct Define It?, 22 J. LEGAL. PROF. 33, $42-44$ (1998) (concluding that "approaches to the drafting of the Model Rules produced a document reflecting standards closer to those of civil law than the standards articulated in the Code" because, unlike the Model Code, the Model Rules "are firmly rooted in positive law," "conform to court-made rules of law," and "recognize the role of customary usage in setting standards of behavior for lawyers"). Compare Geoffirey C. Hazard, Jr., How Far May a Lawyer Go in Assisting a Client in Legally Wrongful Conduct?, 35 U. MiAmI L. Rev. 669, 677-81 (1981), with Monroe H. Freedman, Are the Model Rules Unconstitutional?, 35 U. MiAMl L. REV. 685, 689, 692 (1981) (finding it "significant that Professor Hazard, in discussing the general law relevant to legal ethics, chose to refer to the laws of tort and agency with citation to the Restatement of Agency, but made no reference to constitutional law and no citation to the Bill of Rights" and asserting that "the current revision of the Model Rules, referred to as the final draft, cites none of the foremost constitutional authorities on point to support its position that a lawyer has an obligation to reveal his client's perjury" (footnote omitted)).

31. Restatement (THIRD) of THE Law Governing LaWyers foreword (Tentative Draft No. 8, 1997). Professor Schwartz has a similar analysis: 
matter of both form and authority, it is generally recognized that "when a state supreme court issues an order officially adopting a set of rules of professional conduct, it is establishing legally binding standards of conduct just as a state legislature does when it passes a law proscribing bank robbery."32

The Model Rules in their present form represent the culmination of a historical process that began a century and a half ago: the shift from articulating professional standards, suffused with ideas of morality and ethics, and enforced if at all by informal sanctions and peer pressure, to enacting comprehensive and explicit legislation attended by formally imposed sanctions for breach.

Schwartz, supra note 7, at 953-54.

32. Lawrence K. Hellman, When "Ethics Rules" Don't Mean What They Say: The Implications of Strained ABA Ethics Opinions, 10 GEO. J. LEGAL ETHICS 317, 321 (1997); cf. WOLFRAM, supra note 3, at 67 (finding that "the enforcement of the provisions of lawyer codes in lawyer discipline and other proceedings demonstrates clearly that the codes are legal prescriptions in every conventional sense"); Susan P. Koniak, The Law Between the Bar and the State, 70 N.C. L. REv. 1389, 1411 (1992) (emphasizing that "the state treats ethics rules as 'law' only to the extent that they are (and in the form in which they are) adopted by the state"); L. Ray Patterson, The Function of a Code of Legal Ethics, 35 U. MiAMI L. Rev. 695, 722 (1981) (noting "the fact that the profession only proposes, and the court disposes, since the rules do not become effective until a court adopts them"); Robert Rubinson, Attorney Fact-Finding, Ethical Decision-Making and the Methodology of Law, 45 ST. LoUIS U. L.J. 1185,1188 (2001) (observing that "the primacy of rules as the preeminent object of inquiry in ethics discourse is rarely in question"). The Alaska Supreme Court stated:

The Bar Association ... contends that this appeal is not the appropriate vehicle for modifying [Alaska] Rule [of Professional Conduct] 1.8(e) on policy grounds. Instead it argues that "there is an established procedure for promulgation and adoption of these rules which should not be ignored simply because both parties do not like the present rule." We agree.

In re Matter of K.A.H., 967 P.2d 91, 96-97 (Alaska 1998). But see Stephen E. Kalish, How to Encourage Lawyers to Be Ethical: Do Not Use the Ethics Codes as a Basis for Regular Law Decisions, 13 GEO. J. LEGAL ETHICS 649, 668 (2000) (stating that "ethics codes are not statutes or administrative regulations"); $i d$. at 656 (noting that although "judicial adoption may politically legitimize the written ethics codes[,] ... it is the lawyer-drafters who articulate the rules, and it is the ABA that recommends them."). Strassberg pointed out the lack of democratic approval inherent in ethics codes:

Statutory law's coercive legitimacy stems from its creation by a democratically elected legislature; this legitimacy cannot be transferred to nondemocratic judicial "legislation." In many states, the rules of legal ethics imposed upon the bar are not the product of a democratically elected legislature, but are imposed by the highest court of the state exercising its supervisory powers over lawyers. Although the ABA, which drafted the Model Code and Model Rules, required approval by its House of Delegates before either the Model Code or Model Rules were officially promulgated, and the House voted on all amendments to these models, nonetheless, the models are hardly the sacred products of democracy. This is particularly true since neither the general public nor non-ABA lawyers have a representative voice in the creation of these rules.

Strassberg, supra note 7, at 935-36 (footnotes omitted). In a concurring opinion, Judge Gurfein wrote: 
Nevertheless, despite these developments manifested in both the Model Code and the Model Rules, many scholars have expressed reservations about the extent to which ethics regulations, which include a number of broad provisions, may properly be conceptualized as having attained a legislative form. Perhaps one of the most powerful and prominent voices expressing such a criticism has been that of Professor Wolfram. Despite documenting court decisions generally rejecting arguments that broad ethics provisions are void for vagueness, Wolfram asserts conclusively that "if anything is clear, it is that many provisions of the lawyer codes are plainly imprecise., Wolfram's favorite target is probably Canon 9 of the Model Code, ${ }^{34}$ which mandates, in its title, that "A Lawyer Should Avoid Even the Appearance of Professional Impropriety."35 According to Wolfram, "[i]f carefully analyzed, the appearances standard in any of its incarnations quickly loses much strength." ${ }^{36}$ On a practical level, he argues that the standard lacks a workable methodology, because courts will have difficulty ascertaining the identity of "the observers to whom the relevant appearances present themselves" and because "the judge's task of guessing at what those groups might hold in their minds will be extremely speculative..37 In addition, on a normative level, he questions whether "adverse public reaction [is] generally a basis for [public] decision[s]," particularly in the realm of attorney conduct. ${ }^{38}$ Thus, although he acknowledged in his 1986 hornbook that a number of courts relied on the appearances standard; he concluded in characteristically blunt language that

[i]t stretches the matter to refer to a doctrinal content to the appearances notion. It appears in opinions more in an incantational, intuitive way, and its use is hardly ever defended. Abandoning it would deprive courts

First, I think a court need not treat the Canons of Professional Responsibility as it would a statute that we have no right to amend. We should not abdicate our constitutional function of regulating the Bar to that extent. When we agree that the Code applies in an equitable manner to a matter before us, we should not hesitate to enforce it with vigor. When we find an area of uncertainty, however, we must use our judicial process to make our own decision in the interests of justice to all concerned.

J.P. Foley \& Co. v. Vanderbilt, 523 F.2d 1357, 1359-60 (2d Cir. 1975) (Gurfein, J., concurring).

33. See WOLFRAM, supra note 3 , at 86-87.

34. See id. at 319-23.

35. MODEl CODE OF Prof'L ResPonsibiLity Canon 9 (1981).

36. WolfRAM, supra note 3 , at 320 .

37. Id

38. Id. at 320-21. 
of no useful analytical tool and would fittingly narrow courts' range of [unbridled] discretion in passing on disqualification motions. ${ }^{39}$

More recently, in a 1997 article, Wolfram continued his stronglyworded attack on the appearance of impropriety standard, referring to it as an "antiquated ... concept, which has been discarded almost everywhere." Despite professing to "forego the opportunity to flail, yet again, the mostly dead dog of appearance of impropriety," Wolfram adds that "it is clear that it plays only a minor, if irritating and potentially distorting, role in modern conflicts opinions.",

Though somewhat less caustic in his criticism of other ethics provisions he finds improperly vague, Wolfram attacks them as well because, he asserts, "[u]nnecessary breadth is to be regretted in professional rules that can be used to deprive a person of his or her means of livelihood through sanctions that are universally regarded as stigmatizing." $\mathrm{He}$ argues that such provisions "create several difficulties," including potentially "be[ing] applied corruptly or for reasons of impermissible bias" and "substantially dilut[ing] the procedural protections that otherwise narrow the area within which agencies could act arbitrarily or mistakenly."${ }^{, 43}$

Among the provisions he cites, two of the broadest rules are DR 1-102(A)(5) of the Model Code, later adopted as Model Rule 8.4(d), prohibiting "conduct that is prejudicial to the administration of justice," and DR 1-102(A)(6) of the Model Code, not adopted by the Model Rules, prohibiting "any other conduct that adversely reflects on [the lawyer's] fitness to practice law." ${ }^{944}$ Indeed, Wolfram does not hide his particular disapproval of these two rules, quoting approvingly the

39. Id. at 320 n.38; see also id. at 460-61 (referring to the "Alluring 'Appearances" Rationale" as "a vapid concept sometimes employed independently, and thus quite erroneously, to disqualify a former government lawyer and sometimes as a much less direct and meaningful locution that only obscures a sounder reason" and as creating a "fog" that "has done more to retard thinking on problems of conflicts of former government lawyers than any other concept" (footnotes omitted)); id. at $461 \mathrm{n} .73$ (describing the standard as "virtually empty of intellectual content"). (1997).

40. Charles W. Wolfram, Former-Client Conflicts, 10 GEO. J. Legal EtHICs 677, 686

41. Id. at 686-87. Wolfram further notes that "[a]lmost every scholarly analysis of the 'appearance' standard has disapproved of its use as an independent basis for finding conflict." Id. at $686-87$ n.35; see also Wolfram, supra note 3 , at 322 (stating that "[a]cademic commentators have denounced" the standard); STEPHEN GILLERS, REGULATION OF LAWYERS: PROBLEMS OF LAW AND ETHiCS $358-59$ (6th ed. 2002) (characterizing the standard as unpredictable).

42. WOLFRAM, supra note 3 , at 87 .

43. Id.

44. MODEL CODE OF PROF'L RESPONSIBILITY DR 1-102 (1981). 
view that, together with Canon 9, they comprise "garbage cans of the Code ... into which anything can be tossed., Other scholars have concurred with Wolfram's contention that, notwithstanding the increased specificity found in the Model Code and, to a greater extent, in the Model Rules, lawyer regulations continue to lack the level of specificity appropriate for legislation. ${ }^{46}$

45. WOLFRAM, supra note 3, at 87 n.50 (quoting John F. Sutton, Commentary on the Texas Code of Professional Responsibility, in TeXas LaWYers' Professional ETHICs 6-2, 6 $5 \mathrm{n.37}(1979)$ ). Though again not to the same degree as Canon 9, these provisions have also been subjected, since their inception, to negative academic treatment. See Leonard E. Gross, The Public Hates Lawyers: Why Should We Care?, 29 Seton Hall L. Rev. 1405, 1455 n.245 (1999).

46. See, e.g., Painter, supra note 6, at 669 (arguing that "default rules should be used more extensively in professional responsibility codes" and that "[c]learly-defined default rules could, in some cases, replace the broad standards, permissive rules, or aspirational rules that now govern many controversial topics"); Theodore J. Schneyer, The Model Rules and Problems of Code Interpretation and Enforcement, 1980 AM. B. Found. RES. J. 939, 940 (finding that "on some subjects that were dealt with in the [Disciplinary Rules], but in terms so general as to require heroic interpretive effort, the Model Rules are not appreciably more specific-better written and with fewer internal inconsistencies, but not more specific"); Serena Stier, Legal Ethics: The Integrity Thesis, 52 OHIO ST. L.J. 551, 593 (1991) (describing "the substantial indeterminacies left in the structure of professional ethics by both the Rules and the Code"); $j d$. at 596 n.179 (stating that "[e]ven mandatory standards may leave room for judgment calls"); David B. Wilkins, Legal Realism for Lawyers, 104 HARV. L. REV. 468, 480 (1990) (describing the Model Code as "rife with vague and ambiguous terms," but finding that, while the Model Rules' "self-conscious[ ] attempt to bring more determinacy to the field of professional responsibility by adopting a rule-like structure . . . has eliminated some of the more pervasive ambiguities, vagueness and open-endedness remain").

Some of these criticisms identify aspects of ethics codes that are broader in nature than most forms of legislation. Others, however, invoke aspects of ethics codes that appear to be more reflective of the inherent nature of legal rules that, unavoidably, at times require interpretation of somewhat vague and ambiguous concepts, such as "reasonableness." See, e.g., Painter, supra, at 668 n.19 (citing MODEL RULES of PROF'L CONDUCT R. 1.1, 1.3, 1.4(a) (1983)) (stating that "[t]he 'reasonableness' standard is used to define required levels of competence, diligence, and communication with clients[,] . . but with little guidance as to what conduct is and is not reasonable"); id. at $668 \&$ n.20 (citing MODEL RULES OF PROF'L CONDUCT R. 1.5(a)) (stating that "when the subject matter of a rule is particularly controversial, the rule has tended to remain a standard that is so broad that it is unenforceable" and criticizing the Rule for "stating that [a] lawyer's fee must be reasonable, and listing eight factors to be considered in determining reasonableness, without discussion of which factors are most important"); Wilkins, supra, at 481 (criticizing the Model Rules because, "[a]s under the Model Code, the meaning of 'reasonable' or 'diligent' performance continues to be susceptible to multiple and conflicting interpretations").

As Professor Zacharias has noted, similar "[e]xamples of flexible standards include the reasonableness standards in common law tort rules and the Uniform Commercial Code." Zacharias, supra note 4 , at 237 n.43 (citing several broad U.C.C. provisions and justifications for the use of such flexible rules). In fact, some of the justifications Zacharias cites for broad provisions in the U.C.C., such as the explanation that they are "intended to enable courts to develop law embodied in the Code in the light of unforeseen and new circumstances and practices" appear to apply to broad ethics provisions as well. Id. at 237 n.44 (citing U.C.C. § 1-102 cmt. 1 (1989)); see infra notes 48-54 and accompanying text; see also Koniak, supra 


\section{The NEED FOR AND FUnCTION OF GENERAL RULES IN ETHICS CODES, CONSTITUTIONAL LAW, AND JEWISH LAW}

Defenders of general rules in ethics codes have emphasized the need for and utility of general rules in regulating the ethical conduct of lawyers. In fact, a number of courts have upheld, interpreted, applied, and offered justifications for the kinds of broad ethics provisions that scholars have repeatedly viewed as unworkable and impermissibly vague. ${ }^{47}$ In a 1991 case, the New York Court of Appeals quoted a midnineteenth-century United States Supreme Court opinion acknowledging that "it is difficult, if not impossible, to enumerate and define, with legal precision, every offense for which an attorney or counselor ought to be removed. ${ }^{, 48}$ Therefore, according to the New

note 32, at 1390 ("The law of lawyering is not inherently more amorphous, contradictory or obtuse than other law.").

Nevertheless, Zacharias concludes that "professional codes must be evaluated differently than ordinary legislation and administrative schemes-even those that include legal 'standards' as flexible as the standards in the codes." Zacharias, supra note 4, at 237.

47. See Gillers, supra note 41, at 359 (stating that "one must ... caution against dismissing the 'appearance [of impropriety]' test altogether," in part because "some courts ... may for a time continue to rely on the 'appearance of impropriety' in disqualifying a lawyer"); WOLFRAM, supra note 3, at 86 \& n.48 (observing that "most attacks upon Code provisions charging that they are void for vagueness in violation of the due process clause have been unavailing"); Fred C. Zacharias, Who Can Best Regulate the Ethics of Federal Prosecutors, or, Who Should Regulate the Regulators?: Response to Little, 65 FORDHAM L. REV. 429, 453-54 (1996) (noting "the frequency with which courts cite the 'appearance of impropriety' in their decisions on lawyer disqualification, even though that rationale for ethics regulation increasingly has been downplayed in scholarship and bar-generated codes" (footnotes omitted)).

48. In re Holtzman, 577 N.E.2d 30, 33 (N.Y. 1991) (quoting Ex parte Secombe, 60 U.S. (19 How.) 9, 14 (1856)); see also In re Rinella, 677 N.E.2d 909, 917 (III. 1997) (Freeman, J., concurring in part and dissenting in part) ("As a practical matter, there could never be a set of rules which contemplates every aspect of the many encounters between an attorney and a client."); In re Illuzzi, 632 A.2d 346, 349-50 (Vt. 1993) (referring to the "impossibility of enumerating every act that might constitute a violation of professional standards"); Pantry Pride, Inc. v. Finley, Kumble, Wagner, Heine, Underberg \& Casey, 697 F.2d 524, 530 (3d Cir. 1982) (stating that "[t]he appearance of impropriety standard is necessarily vague"); In re Hinds, 449 A.2d 483, 498 (N.J. 1982) (noting that "[a]ttorney disciplinary rules have long been framed in general, rather sweeping language"); Comm. on Prof'l Ethics v. Durham, 279 N.W.2d 280, 284 (lowa 1979)(stating that "guidelines setting standards for members of the bar need not and cannot meet the standard of clarity required of rules of conduct for laymen due to the training and specialized nature of the body being regulated"). The court also stated that

standards relating to the conduct of attorneys may also be distinguished in that it would be virtually impossible to develop a set of rules to specifically cover all professional activity which could merit discipline, thus necessitating broader standards. The bar must be concerned about the professional activities of its members, and the manner in which these activities reflect upon the integrity of the profession as a whole. 
Id.

Likewise, a number of scholars - among them critics of the broad nature of certain ethics provisions - have acknowledged the utility of broad rules. See, e.g., Heidi Li Feldman, Codes and Virtues: Can Good Lawyers Be Good Ethical Deliberators?, 69 S. CAL. L. ReV. 885,899 (1996) ("Instances of inconclusiveness arise in all areas of the law, including those governed by relatively specific fine-grained rules and regulations. The only way to eliminate inconclusiveness entirely would be to devise a rule to cover every particular case of ethical difficulty-an impossible task, because the cases are infinite."); Kutak, supranote 26, at 1019 ("II]t is conceivable that a code could prescribe conduct with the minute detail of the Internal Revenue Code, but such specificity would be burdensome and inhibiting and might have an equally adverse impact on enforcement and compliance."); Painter, supra note 6, at 689 (suggesting that in some areas of ethics codes, "a standard is used because a defined rule's prohibitions might sweep too broadly"). Painter went on to state:

Sometimes the bar prefers that an immutable rule be a standard rather than a defined rule if there is substantial disagreement over what the rule should be. Because immutable rules are inflexible ex ante (they cannot be contracted around), rulemakers who disagree on basic principles underlying a rule are not likely to select an immutable rule that is so well defined that it is also inflexible ex post (preventing an adjudicator from tailoring the rule to adjust for circumstances).

Id. at 690; see also Strassberg, supra note 7, at 902 (observing that "in legal ethics, cases must arise which will not fit within an existing rule"); Wilkins, supra note 46, at 500 ("Formulating more precise rules could reduce the level of indeterminacy in the system. But this clarity comes at a price. By their very nature, rigid rules are either over- or underinclusive (or both) relative to their intended purposes." (footnotes omitted)). Zacharias offered the following analysis:

By making the elements of [a code provision] unambiguous, drafters run the risk of defining the misconduct so narrowly that it becomes inapplicable to most situations sought to be covered .... For example, adding a state of mind element (e.g., intent) or a reasonableness element to the confidentiality rules might eliminate those situations in which lawyers gossip irresponsibly about their clients or use confidential information, without authority, for the clients' benefit. If the amended rule is deemed to cover those situations, enforcers must deal with the fact that extrinsic proof of intent and reasonableness generally are not available.

Zacharias, supra note 4 , at $253 \mathrm{n} .93$; id. at 255 (noting that "a highly specific provision that merely restates, or duplicates, extra-code standards may influence behavior less than a general rule that lawyers might interpret as applying more broadly"); id. at $277 \mathrm{n} .162$ (citing H.L.A. HART, THE CONCEPT OF LAW 123-32 (1961)) (noting Hart's "preference for generality in lawmaking when legislating in new areas of law, because this generality enables the law to evolve more easily (usually judicially) over time[,] ... [while] [b]y contrast, highly specific laws tend to remain fixed," and concluding that "[t]he same analysis applies with respect to judicial adoption of specific professional code provisions [that] tend to control courts and limit their ability to adjust as unforeseen cases arise"). See generally Russell W. Damtof, Note, Lawyer Disciplinary Standards: Broad vs. Narrow Proscriptions, 65 IowA L. Rev. 1386 (1980). Damtoft states:

Narrow rules of conduct, it is argued, cannot be drawn to encompass every variety of unethical behavior. Therefore, some broad standards must be combined with narrow rules to ensure that attorneys are disciplined for unforeseen types of misconduct. This position is reflected in the several broad disciplinary rules included in the ABA [Model] Code. A related danger is that attorneys inevitably will use the narrowness of some rules to create loopholes for marginal behavior, loopholes that are closed by broad standards. 
York court, it follows that "[b]road standards governing professional conduct are permissible and indeed often necessary.",49

Indeed, the Preamble to the 1908 Canons of Professional Ethics contained a similar assertion that

[n]o code or set of rules can be framed, which will particularize all the duties of the lawyer in the varying phases of litigation or in all the relations of professional life. The following canons of ethics are adopted by the American Bar Association as a general guide; yet the enumeration of particular duties should not be construed as a denial of the existence of others equally imperative, though not specifically mentioned. ${ }^{50}$

The Preamble is instructive not only because it appears to serve as an analog to the rationale that contemporary courts have offered for the inclusion of broad provisions in ethics codes. Perhaps more importantly, through its striking similarity to principles of constitutional interpretation, the Preamble may have profound ramifications for the interpretation and application of contemporary ethics codes.

In addition to, and premised on, its observation of the necessarily and inherently incomplete nature of ethics codes, the Preamble prescribes adherence to unenumerated ethical obligations as well as to those enumerated. Thus, the Preamble anticipated an approach to unenumerated constitutional rights that would be invoked decades later by Justice Goldberg in his explanation of the function of the Ninth

Id. at 1399 (footnotes omitted). The two broad Model Code provisions cited to support this analysis are DR 1-102(A)(5) and DR 1-102 (A)(6). Id.

49. Holtzman, 577 N.E.2d at 33; see also In re Rinella, 677 N.E.2d 909, 914 (III. 1997) (stating that "the standards of professional conduct enunciated by this court are not a manual designed to instruct attorneys what to do in every conceivable situation"). The court quoted the preamble to the Illinois Rules of Professional Conduct:

No set of prohibitions, however, can adequately articulate the positive values or goals sought to be advanced by those prohibitions. This preamble therefore seeks to articulate those values .... Lawyers seeking to conform their conduct to the requirements of these rules should look to the values described in this preamble for guidance in interpreting the difficult issues which may arise under the rules.

Id. at 914 (quoting ILL. RULES OF PROF'L CONDUCT preamble at 470); Santa Clara County Counsel Attorneys Ass'n v. Woodside, 28 Cal. Rptr. 2d 617, 629 (1994) ("Although the question of an attorney's suit against a present client is not explicitly covered in the Rules of Professional Conduct, or by any statute ... [i]t is clear that the duties to which an attorney in this state are subject are not exhaustively delineated by the Rules of Professional Conduct."); In re N.P., 361 N.W.2d 386, 395 (Minn. 1985) (quoting In re Gillard, 271 N.W.2d 785, 809 n.7 (Minn. 1978)).("We ourselves have, in the comparable situation of applying a legislative standard of judicial conduct, similarly recognized that 'necessarily broad standards of professional conduct' are constitutionally permissible.").

50. Canons of Professional ETHiCS preface (1908). 
Amendment in the United States Constitution." According to Justice Goldberg, the Ninth Amendment "was proffered to quiet expressed fears that a bill of specifically enumerated rights could not be sufficiently broad to cover all essential rights and that the specific mention of certain rights would be interpreted as a denial that others were protected.".52

Moreover, the language of the prescription in the Preamble of the Model Code appears closely modeled after the Ninth Amendment, which states: "The enumeration in the Constitution, of certain rights, shall not be construed to deny or disparage others retained by the people." ${ }^{33}$ The similarity in both form and substance of the Preamble and the Ninth Amendment is indicative of a more significant similarity in the interpretive methodologies courts have employed in the interpretation of ethics codes and constitutional interpretation, by deriving and identifying unenumerated ethical obligations and

51. U.S. CONST. amend. IX ("The enumeration in the Constitution, of certain rights, shall not be construed to deny or disparage others retained by the people.").

52. Griswold v. Connecticut, 381 U.S. 479, 488-89 (1965) (Goldberg, J., concurring); see Randy E. Barnett, Reconceiving the Ninth Amendment, 74 CORNELL L. REV. 1, 10 (1988) (reprinting an excerpt from a speech in which then-Representative James Madison voiced concern that "by enumerating particular exceptions to the grant of power, it would disparage those rights which were not placed in that enumeration; and it might follow by implication, that those rights which were not singled out ... were consequently insecure" (quoting I THE Debates and Proceedings in the Congress of the United States 456 (J. Gales \& W. Seaton eds., 1834)). In Moore v. City of East Cleveland, Justice Goldberg stated:

[T] ] full scope of the liberty guaranteed by the Due Process Clause cannot be found in or limited by the precise terms of the specific guarantees elsewhere provided in the Constitution. This 'liberty' is not a series of isolated points pricked out in terms of the taking of property; the freedom of speech, press, and religion; the right to keep and bear arms; the freedom from unreasonable searches and seizures; and so on. It is a rational continuum which, broadly speaking, includes a freedom from all substantial arbitrary impositions and purposeless restraints. . . .

431 U.S. 494, 502 (1977) (Powell, J., concurring) (quoting Poe v. Ullman, 367 U.S. 497, 543 (I961) (Harlan, J., dissenting)).

As I have observed elsewhere, the justices adopting this approach acknowledged that "a proper understanding of the guarantees of liberty requires looking beyond the specific rights enumerated in the Constitution, to uncover the underlying principles those rights represent." Samuel J. Levine, Unenumerated Constitutional Rights and Unenumerated Biblical Obligations: A Preliminary Study in Comparative Hermeneutics, 15 CoNST. CoMM. 511 , 515 (1988). Likewise, the Preamble and courts that have interpreted and applied broad ethics provisions adhere to the position that a proper understanding of the obligations and responsibilities mandated by ethics codes requires looking beyond the specific obligations enumerated in the codes, to uncover the underlying principles those obligations represent.

53. U.S. CoNST., amend. IX. 
unenumerated constitutional rights through the interpretation and application of broad provisions. ${ }^{54}$

Extending these concepts beyond the American legal system, the Jewish legal system provides a third set of legal rules consisting in part of broad provisions that are interpreted to derive unenumerated laws. Many centuries ago, offering justifications similar to those offered in contemporary times for broad provisions in ethics codes and in the Constitution, Nachmanidess ${ }^{s 5}$ explained that, notwithstanding the numerous and wide-ranging positive and negative commandments delineated in the Torah, ${ }^{36}$

54. Likewise, the Preamble's insistence that the unenumerated obligations are "equally imperative" as those obligations enumerated in the Canons presents a further parallel to the way some scholars have understood the Ninth Amendment. See, e.g., Charles L. Black, Jr., On Reading and Using the Ninth Amendment, in POWER AND POLICY IN QUEST OF LAW: ESSAYS IN HONOR OF EUGENE VICTOR ROSTOW I87 (Myers S. McDougal Cougar \& W. Michael Reisman eds., 1988). Black asserted that the Ninth Amendment requires equal treatment of all rights:

[P]reponderance of reason leaves us with the conclusion, about as well-supported as any we can reach in law, that the Ninth Amendment declares as a matter of lawof constitutional law, overriding other law-that some other rights are "retained by the people," and that these shall be treated as on an equal footing with rights enumerated.

Id. at 188.

55. Nachmanides (1195-c. 1270), also known by the acronym Ramban (Rabbi Moshe ben Nachman), was a leading Medieval Jewish legal scholar, philosopher, and biblical commentator. See Charles B. Chavel, Ramban, His Life and TEaChings (1960); Charles B. Chavel, Preface to 1 Moses Ben Nachman, Ramban (NaChManides), Commentary on THE TORAH (Charles B. Chavel, trans., 1971) [hereinafter NACHMANIDES].

56. See Samuel J. Levine, An Introduction to Legislation in Jewish Law, with References to the American Legal System, 29 SeTON HALl L. Rev. 916, 920 (1999). Scholars of Jewish law identify 613 commandments enumerated in the Torah, covering nearly every area of human activity. See MAIMONIDES, SEFER HA-MITzVOTH (Soncino 1940); SEFER HAHINNUCH: THE BOOK OF MitzVAH EdUCATION (Charles Wengrov trans., 1985); see also Samuel J. Levine, Professionalism Without Parochialism: Julius Cohen, Rabbi Nachman of Breslov, and the Stories of Two Sons, 71 FordHaM L. Rev. 1339 (2003); Samuel J. Levine, The Broad Life of the Jewish Lawyer: Integrating Spirituality, Scholarship and Profession, 27 TEX. TECH L. REv. 1199, 1199 (1996) (describing the interaction of the legal profession and a "set of religious laws and principles [that] govern[] every area of life"); $c f$. JOSEPH B. SOLOVEITCHIK, HALAKHIC MAN 33 (Lawrence Kaplan trans., 1983) (originally published in Hebrew as Ish ha-halakhah, in 1 TALPIOT 3-4 (1944)) ("The task of the religious individual is bound up with the performance of commandments, and this performance is confined to this world, to physical, concrete reality, to clamorous, tumultuous life, pulsating with exuberance and strength."); Moshe Silberg, Law and Morals in Jewish Jurisprudence, 75 HARV. L. REV. 306,309 (1961) ("[U]nlike the overwhelming majority of other legal systems, Jewish law does not confine itself to relations between man and man, but in addition defines in legal categories, applies legal terms, perceives through legal concepts, the relationship between man and God ...."); id. at 322 ("The Jew's mode of dress, his diet, dwelling, behavior, relation with men, his family affairs, and his business affairs were all prefixed and premolded, 
it would be impossible to mention in the Torah all aspects of man's conduct with his neighbors and friends, and all his various transactions, and the ordinances of all societies and countries. But since [God] mentioned many of them ... [God] reverted to state in a general way that, in all matters, one should do what is good and right .... Thus, [a person must seek to refine his behavior] in every form of activity ....

Indeed, expressing a concern strikingly similar to that which Justice Goldberg later cited to explain the importance of the Ninth Amendment in the constitutional framework, Nachmanides acknowledges the potential danger of an individual claiming adherence to those obligations enumerated in the Torah, yet engaging in wrongful activities that are not expressly prohibited: "[A]nd thus he will become a sordid person within the permissible realm of the Torah..\$58 Therefore, he continues, "after having listed the matters which [God] prohibited altogether Scripture followed them up by a general command that we [be holy] .... And such is the way of the Torah, that after it lists certain specific prohibitions, it includes them all in a general precept.:

Thus, as in interpretation of both ethics codes and constitutional provisions, Jewish legal theory views broad provisions as a necessary basis for the derivation of unenumerated principles. In fact, Jewish law may provide a particularly helpful interpretive model for the analysis of ethics codes because both focus on and prescribe obligations rather than rights. Robert Cover famously contrasted the American legal system with the Jewish legal system through the

in a national cloak, in a set of laws that was clear, severe, strict, detailed, that accompanied him day by day, from cradle to grave.").

In addition, many of these commandments can further be divided into component parts, resulting in a substantially larger number of enumerated obligations. Finally, there exist other imperatives that, although for methodological reasons are not tallied as commandments, nonetheless present yet additional enumerated obligations. See generally MAIMONIDES, supra.

57. 5 NACHMANIDES, supra note 55, at 88 (explicating Deuteronomy 6:18); see also YOSEPH ALBO, SEFER HA-IKKARIM 3:23, quoted in MENACHEM ELON, JEWISH LAW: HISTORY, SOURCES, PRINCIPLES (Bernard Auerbach \& Melvin J. Sykes trans., 1994). Rabbi Albo explained:

It is impossible for the Torah of God to have covered all possible cases that may ever arise, because the new situations that constantly arise in human affairs, in law, and as a result of human enterprise are so manifold that a book cannot encompass them. Therefore, general principles, which the Torah only briefly suggests, were revealed orally to Moses at Sinai, so that the halakhic authorities of every generation would use them to derive new laws.

Id. at 241 (footnotes omitted).

58. 3 NACHMANIDES, supra note 55, at 282 (explicating Leviticus 19:2).

59. Id. at $282-83$. 
observation that "[t]he principal word in Jewish law, which occupies a place equivalent in evocative force to the American legal system's 'rights,' is the word 'mitzvah' which literally means commandment but has a general meaning closer to "incumbent obligation." ${ }^{\text {"10 }}$ By its nature, the notion of unenumerated constitutional rights may epitomize Cover's characterization of a rights-based jurisprudence underlying American law. Ethics codes, however, appear to comprise a somewhat

60. Robert M. Cover, Obligation: A Jewish Jurisprudence of the Social Order, 5 J.L. \& RELIGION 65, 65 (1987); see also SOL ROTH, HALAKHA AND POLITICS: THE JEWISH IDEA OF THE STATE 97 (1988) (describing Jewish law's "supreme concern with duties or obligations"); Levine, supra note 7, at 499 ("Jewish law imposes many duties and obligations on the individual that are inconsistent with Western definitions of 'liberty' and autonomy."); Silberg, supra note 56, at 313-14 (observing that "modern law has no interest in duties; its sole interests are rights" and that "[o]ne cannot strike the words 'to have a right' from the modern legal dictionary, but it is definitely possible to exist without the words 'to be obliged," in contrast with "the great value which Jewish law attributes to the duty of fulfilling the legal obligation ... [ [which] is neither exhausted by nor limited to the possibility of civil realization of the ... right of action, as in other legal systems, but relies on, and to no small extent, the religious-moral duty"). Steven F. Friedell, Aaron Kirschenbaum on Equity in Jewish Law, 1993 BYU L. REV. 909, 913 (book review) ("American law, for example, places a high value on individualism, free enterprise, and privacy. Jewish law, while not always opposed to these goals, has other aspirations that may cause conflict[, including] ... the maintenance of a religious community committed to mutual support through acts of loving kindness.").

Despite this general distinction, in some areas, such as the rights of criminal defendants, Jewish law appears to offer greater protections than American constitutional law. See, e.g., Donald L. Beschle, What's Guilt (or Deterrence) Got to Do with It?: The Death Penalty, Ritual, and Mimetic Violence, 38 WM. \& MARY L. REv. 487, 508 (1997) (stating that "[t] he procedural demands necessary to sustain a capital sentence [in ancient Israel] were increased to a level that would [have] put the Warren Court to shame"); Samuel J. Levine, Capital Punishment in Jewish Law and Its Application to the American Legal System: A Conceptual Overview, 29 ST. MARY'S L.J. 1037, 1040-41 (1998) [hereinafter Levine, Capital Punishment in Jewish Law] (citing the Talmud's description of the "painstaking procedural safeguards that were required to be observed before the death penalty could be carried out"); id. at 1045-46 (noting that "[s]uch safeguards were implemented throughout the Jewish criminal justice process, including during the apprehension of the individual, the introduction of evidence at trial, the deliberations, the rendering of a verdict, and post-verdict proceedings [,] ... produc[ing] a criminal justice system in which the death penalty was implemented somewhat infrequently"); Irene Merker Rosenberg \& Yale L. Rosenberg, In the Beginning: The Talmudic Rule Against Self-Incrimination, 63 N.Y.U. L. REv. 955, 956 (1988) (contrasting the American privilege against self-incrimination with the rule in Jewish law that, "with few exceptions, effectively precluded the admission of any confession of guilt in both criminal and quasi-criminal cases, whether by defendant or witness, in-court or out-of-court, voluntary or coerced, spontaneous or elicited").

Yet even these apparent exceptions may instead lend further support to the depiction of an obligation-based jurisprudence underlying the Jewish legal system, as the rights accorded a criminal defendant were in part an extension of the interpersonal obligations of saving others and protecting the sanctity of human life. See, e.g., RABBI HERSHEL. SCHACHTER, Eretz Hatzevi 243-48 (1992); Talmud Bavli, Pesachim 12a (explicating Numbers 35:25); Rosh Hashana 26a (same); Sanhedrin 69a (same); Levine, Capital Punishment in Jewish Law, supra, at 1047; Samuel J. Levine, Capital Punishment and Religious Arguments: An Intermediate Approach, 9 WM. \& MARY BILL RTS. J. 179, I88-89 (2000). 
unique area of American law in which obligation-the ethical obligations incumbent upon a lawyer-plays a central role. ${ }^{.1}$ Therefore, for the purpose of comparative hermeneutic analysis, American ethics codes seem, in this sense, more similar to Jewish law than to American constitutional law.

\section{DERIVING AND IDENTIFYING UNENUMERATED ETHICAL OBLIGATIONS: AN EXERCISE IN COMPARATIVE HERMENEUTICS}

A close look at the interpretive methods that have been applied to ethics codes, the United States Constitution, and the Torah may reveal a common approach to the derivation and articulation of unenumerated principles based on a common hermeneutic methodology employed in the interpretation of broad provisions. The following analysis, therefore, builds on the work of scholars who have compared constitutional interpretation to biblical interpretation. ${ }^{62}$

Specifically, this analysis examines three related but conceptually distinct interpretive methodologies, each of which has been used to derive both unenumerated constitutional rights and unenumerated biblical obligations, ${ }^{63}$ then posits that these three methodologies may be applied to derive unenumerated ethical obligations as well. The analysis is presented both on a descriptive level, through a sampling of court decisions that have employed these methods to interpret broad ethics provisions, and on a more theoretical level, through an examination of the underlying normative rationale behind the use of

61. Cf. Susan P. Koniak, Through the Looking Glass of Ethics and the Wrongs with Rights We Find There, 9 GEO. J. LEGAL ETHICS 1, 28-29 (1995) (elaborating on Cover's analysis, stating that "[u]nlike tax law, tort law or other sources of legal obligation in our normative world, ethics is not merely a source of obligation but the place where obligation is understood as dignifying and ennobling" and that "[i]n legal and judicial ethics we find the possibility of dignifying obligations that are enforceable as law").

62. See Steven D. Smith, Believing Like a Lawyer, 40 B.C. L. Rev. 1041, 1068 (1999) ("TT]he similarities between legal and scriptural interpretation are so imposing that they have been noticed by a number of modern legal scholars."); see, e.g., SANFORD LEVINSON, CONSTITUTIONAL FAITH (1985); Robert M. Cover, The Supreme Court 1982 Term, Foreword: Nomos and Narrative, 97 HaRv. L. Rev. 4 (1983); David R. Dow, Constitutional Midrash: The Rabbis' Solution to Professor Bickel's Problem, 29 Houston L. Rev. 543 (1992); Ronald R. Garet, Comparative Normative Hermeneutics: Scripture, Literature, Constitution, 58 S. CAL. L. Rev. 35 (1985); Thomas C. Grey, The Constitution as Scripture, 37 STAN. L. ReV. 1 (1984); Levine, supra note 7; Levine, supra note 52; Steven D. Smith, Idolatry in Constitutional Interpretation, 79 VA. L. REV. 583 (1993).

63. Although this analysis borrows briefly from the framework developed in Levine, supra note 52 , the present discussion provides both different emphasis and additional insights more appropriate to the application of the framework to the interpretation of ethics codes. 
these methods in the interpretation of ethics codes, the Constitution, and the Torah.

\section{A. Interpretive Methodologies Employed in the Derivation of Unenumerated Constitutional Rights and Unenumerated Biblical Obligations}

(1) The first method involves interpretation of a broad term in the text of a legal provision to include additional unenumerated applications of the provision as understood through traditions transmitted largely outside of the interpretive process. ${ }^{64}$ In constitutional interpretation, the United States Supreme Court has interpreted the Fourteenth Amendment's guarantee of "liberty" include the freedom "to enjoy those privileges long recognized at common law as essential to the orderly pursuit of happiness by free men." ${ }^{\text {"66 }}$ Thus, in Meyer v. Nebraska, the Court determined that "[ $\left.t\right]$ he American people have always regarded education and acquisition of knowledge as matters of supreme importance which should be diligently promoted.".67 As a result, the Court struck down a Nebraska state law prohibiting teaching any language other than English prior to

64. See Levine, supra note 52, at 512-17.

65. U.S. CoNST. amend. XIV, $\S 1$ (stating, in relevant part, "[n]o State shall ... deprive any person of life, liberty, or property, without due process of law").

66. Meyer v. Nebraska, 262 U.S. 390,399 (1923). For a discussion of subsequent cases relying on a similar understanding of the term "liberty," see Levine, supra note 53, at 512-15. More recently, writing the plurality opinion in Troxel v. Granville, 530 U.S. 57 (2000), Justice O'Connor cited Meyer, 262 U.S. at 390, and its progeny in support of the proposition that "[ $t]$ he liberty interest at issue in this case-the interest of parents in the care, custody, and control of their children-is perhaps the oldest of the fundamental liberty interests recognized by this Court." Troxel, 530 U.S. at 65 (O'Connor, J., piurality opinion); see also id. at 66 ( $O^{\prime}$ Connor, J., plurality opinion) (citing a number of more recent cases as "extensive precedent, it cannot now be doubted that the Due Process Clause of the Fourteenth Amendment protects the fundamental right of parents to make decisions concerning the care, custody, and control of their children". The Washington Court observed:

[Under o] ur established method of substantive-due-process analysis ... we have regularly observed that the Due Process Clause specially protects those fundamental rights and liberties which are, objectively, "deeply rooted in this Nation's history and tradition" and "implicit in the concept of ordered liberty," such that "neither liberty nor justice would exist if they were sacrificed."

Washington v. Glucksberg, 521 U.S. 702, 720-21 (1997) (citations omitted); $i d$. at 721 ("Our Nation's history, legal traditions, and practices ... provide the crucial 'guideposts for responsible decisionmaking,' that direct and restrain our exposition of the Due Process Clause." (citation omitted)); id. at 727 \& n.19 (citing cases identifying "those personal activities and decisions that this Court has identified as so deeply rooted in our history and traditions, or so fundamental to our concept of constitutionally ordered liberty, that they are protected by the Fourteenth Amendment").

67. Meyer, 262 U.S. at 400. 
high school, concluding that the teacher's "right thus to teach and the right of parents to engage him so to instruct their children ... are within the liberty of the Amendment.,968

Similarly, Jewish legal authorities have interpreted the broad command "you shall be holy"69 to require adherence to unenumerated obligations, identifiable through reference to historical narrative and traditions. $^{70}$ For example, Nachmanides notes that the Torah does not enumerate a prohibition against drunkenness. ${ }^{1}$ Nevertheless, he concludes, the general command to be holy includes a prohibition against actions that violate the concept of holiness, including drunkenness. ${ }^{22}$ An express prohibition is unnecessary, he explains, as the spiritual vices and dangers of drunkenness are part of the narrative tradition, delineated in the stories of Noah and Lot, and thus are incorporated in the enumerated command to be holy. ${ }^{73}$

(2) The second method of deriving unenumerated rights and obligations looks to the substance of the rules that are enumerated and applies the broad principles underlying those rules, extending the protections and obligations to unenumerated circumstances as well. ${ }^{74}$ In Griswold v. Connecticut, the United States Supreme Court explained that "specific guarantees in the Bill of Rights have penumbras, formed by emanations from those guarantees that help give them life and substance."' Thus, the Court stated, "[v]arious guarantees create zones of privacy."76 Applying these principles to a Connecticut statute prohibiting contraceptives, after describing at

68. Id.

69. Leviticus 19:2.

70. See Levine, supra note 52, at 515-17. For a discussion of the relationship between law and narrative in Jewish legal theory, including the normative relevance of narrative and the interplay between legal precepts and narrative in the Torah and other primary and secondary sources of Jewish law, see Samuel J. Levine, Halacha and Aggada: Translating Robert Cover's Nomos and Narrative, 1998 UTAH L. REV. 465 (explicating Cover, supra note 62).

71. See 3 NACHMANIDES, supra note 55, at 282 (explicating Leviticus 19:2).

72. See id. at 283.

73. See id. (citing Genesis 9:21, 19:33); see also MAIMONIDES, MishNE TORAH, Laws of $D e^{\prime}$ oth $5: 3$; Laws of Festivals 6:20-21.

For a summary of the debate among legal authorities about whether-and if so, to what extent-the celebration of the holiday of Purim presents an exception to this general prohibition, see Shlomo Yosef ZEvin, HamOAdim B'HALACHA 203-08 (1955). For a normative analysis of the position that the prohibition is suspended for the celebration of Purim, and an explanation of the sui generis nature of Purim in this regard, see YITZCHAK HUtNeR, PACHAD YITZCHAK, PURIM 81-82 (6th ed. 1998).

74. See Levine, supra note 52, at 517-22.

75. 381 U.S. 479,484 (1965).

76. Id. 
length various unenumerated constitutional protections that stem from such penumbras, the Court found that the statute similarly "concern[ed] a relationship lying within the zone of privacy created by several fundamental constitutional guarantees." On that basis, the Court struck down the statute as "repulsive' to the notions of privacy surrounding the marriage relationship."78

In Jewish law, Nachmanides' commentary on the Torah again presents a parallel interpretive methodology, in his analysis of the command to "do the just and the good." According to Nachmanides, this broad command is another source for the requirement to adhere to obligations beyond those enumerated in the text of the Torah. ${ }^{80}$ The identity of these obligations is derived through an examination of the principles underlying numerous enumerated obligations, such as respecting elders, preventing harm to others, and not seeking revenge. ${ }^{8 !}$ Based on these principles, Nachmanides concludes that the command to adhere to "just and good" behavior extends to such varied unenumerated areas of interpersonal conduct as according neighbors the right of first refusal on land, dressing and speaking to others in a respectful manner, and behaving in a cooperative manner in litigious settings. ${ }^{82}$

(3) Finally, a third method for deriving unenumerated constitutional rights is reliance on the Ninth Amendment. ${ }^{83}$ In his famous concurrence in Griswold, Justice Goldberg argued that the Ninth Amendment provides a source for the unenumerated right of privacy in marriage, including the right to use contraceptives. ${ }^{84}$ More generally, he concluded, the history and broad language of the Ninth Amendment demonstrated that "the Framers of the Constitution believed that there are additional fundamental rights, protected from governmental infringement, which exist alongside those fundamental rights specifically mentioned in the first eight constitutional amendments." ${ }^{95}$ Notwithstanding the logic of this position, apparently concerned that the amendment is cast in terms that are, in fact, too

77. $J d$. at 485 .

78. Id. at 486 .

79. See 5 NACHMANIDES, supra note 55, at 87-88 (explicating Deuteronomy 6:18); Levine, supra note 52, at 520-22.

80. See 5 NACHMANIDES, supra note 55 , at 87-88.

81. See id. at 88 (citing Leviticus 19:16, 18, 32).

82. See id. at 88 .

83. See Levine, supra note 52 , at $522-26$.

84. Griswold v. Connecticut, 381 U.S. 479; 487 (1965) (Goldberg, J., concurring).

85. Id. at 488 (Goldberg, J., concurring). 
broad to apply, the Court has generally resisted attempts to turn to the Ninth Amendment to derive and identify unenumerated constitutional rights. $^{86} \quad$ Nevertheless, at least on a theoretical level, the Ninth Amendment retains its significance and has been embraced by numerous scholars as a valuable tool in constitutional interpretation. ${ }^{87}$

Here again, Jewish law offers a striking parallel, in the broad command to "love your neighbor as yourself." Throughout history, in interpreting this command, Jewish legal authorities have universally agreed that it requires "not only [] sentiment, but [] action, which is motivated by sentiment." Given the number and range of enumerated laws governing interpersonal relationships, the powerful prescription to love one's neighbor as one's self has been understood as a source of rather extensive unenumerated interpersonal obligations. ${ }^{90}$ Similar to the Ninth Amendment, the precise legal contours of this broad rule have been the subject of differing interpretations, ${ }^{91}$ though unlike the Ninth Amendment, there is no debate as to the legal force of the rule.

86. See infra notes 162-164 and accompanying text.

87. See infra notes 165-167 and accompanying text.

88. Leviticus 19:18; see Levine, supra note 52, at 525-26.

89. JoSEPH B. SOLOVEITCHIK, FAMILY REDEEMED 40 (David Schatz \& Joel Wolowelsky eds., 2000).

90. Analyzing statements in the Talmud and in the work of Maimonides, Rabbi Soloveitchik identifies and conceptualizes three interpretations of the command:

The first interpretation, phrased in the negative, says that the I must recognize the existence of the thou, I must see thou as real. This act of acknowledgment contains ipso facto a contractual relationship with the basic clause that guards the rights of the other in the same manner as I want my prerogatives to be protected from unjust infringement. The relationship is of a juridic nature. There is a solidarity awareness; yet solidarity is not to be equated with community. We must not speak of a union. The autonomy has not been completely eliminated. One considers the thou as the other self who is not to be equated with the I .... [N]o existential union has been formed as yet. The thou has not entered the I, nor has the I been admitted into the thou. The second ... interpretation points toward a higher level of interhuman relationship. The latter is raised from an awareness of neutral facticity to an awareness of ontic solidarity. The third notion proclaims "union of being." Individual existence ceases to be solitary. It becomes a community existence, a fellowship of [acts of kindness], rooted in an awareness of unity.

Id. at 143-46 (citing TALMUD BAVLI, Shabbath 31a; MAIMONiDES, supra note 73, Laws of Mourning 14:1; TALMUD BAVLI, Bava Metzia 62a); see also Reuven P. Bulka, Love Your Neighbor: Halachic Parameters, 16 J. HALACHA \& CONTEMP. SOC'Y 44 (1988); YITZCHAK HutNer, PACHAD YitzchaK, Pesach 73-76 (6th ed. 1999).

91. See supra note 90 . 
B. Applying the Interpretive Methodologies: Deriving and Identifying Unenumerated Ethical Obligations

Courts interpreting ethics codes have, at times, relied on methods similar to those employed in both constitutional law and Jewish law to derive unenumerated legal principles from principles that are enumerated. In particular, a number of courts have found that broad ethics provisions provide a source for the derivation, identification, and application of ethical obligations beyond those expressly enumerated in the text of ethics codes. Thus, notwithstanding the criticisms of Wolfram and other scholars, ${ }^{92}$ rather than rejecting broad ethics provisions, these courts have affirmed the normative and practical utility of such rules as a valuable tool in ethics interpretation. The courts' application of these methods is perhaps most apparent and in light of enduring scholarly criticism, perhaps most striking, in the interpretation of rules that prohibit "conduct that adversely reflects on [the lawyer's] fitness to practice law" to the administration of justice" ${ }^{194}$ and that require avoiding the "Appearance of Professional Impropriety."9s

\section{DR 1-102(A)(6): "Conduct that Adversely Reflects on [the Lawyer's] Fitness to Practice Law"}

The first of these provisions has faced the concerns of scholars and judges who, in the words of one early critic, lack "confidence in an enlightened application of the ... clause because [they are] uncertain what conduct will be held to reflect adversely on fitness to practice law."' These concerns over the broad, and potentially vague, nature of the rule were echoed by the Court of Appeals of Maryland in rejecting an appeal of a trial court's refusal to find a violation of DR 1-

92. See supra notes $33-45$ and accompanying text.

93. MODEL CODE OF PROF'L RESPONSIBILITY DR 1-102(A)(6) (1981).

94. MODEL CODE OF PROF'L RESPONSIBIUTY DR 1-102(A)(5); MODEL RULES OF PROF'L CONDUCT R. 8.4(d).

95. MODEl CODE OF PROF'L RESPONSIBILITY Canon 9. For a similar approach to broad rules, applied in a very different context, see Martin Kosla, Disciplined for "Bringing a Sport into Disrepute"-A Framework for Judicial Review, 25 MELB. U. L. REv. 654 (2001). Kosla observes that because "[i]t is not possible for the rules and codes of conduct to expressly provide for all misbehaviour that may have an adverse effect on a sport[,] ... widereaching clauses are employed to catch misconduct that falls outside the scope of specific rules." Id. at 655 . He concludes that "[n]otwithstanding its imprecise nature, closer examination of the case law reveals that the disrepute clause does have boundaries and limits". Id. at 666.

96. Donald T. Weckstein, Maintaining the Integrity and Competence of the Legal Profession, 48 Tex. L. Rev. 267, 276 (1970). 
102(A)(6). ${ }^{97}$ The bar counsel argued that the trial court should have found that a lawyer's "allowing his position as an attorney to be used to induce persons to invest in a scheme that turned out to be fraudulent amounts to conduct that adversely reflects on his fitness to practice law."98 The appellate court found that the bar counsel's contention "paints with too broad a brush" and instead concluded that "[t]he specific conduct relied upon to demonstrate a lack of fitness to practice law is properly considered under the specific charges of inadequate preparation and neglect (DR 6-101), but not as a predicate for finding a violation for DR 1-102(A)(6)."99

Nevertheless, in practice, "most courts have upheld [broad ethics] provisions against constitutional attacks on the grounds of vagueness and overbreadth." ${ }^{\prime 100}$ Many courts upholding rules modeled after DR 1102(A)(6) have relied on the reasoning offered by the United States Supreme Court in upholding court rules invoking the similar concept of "conduct unbecoming a member of the bar of the court."101 In a 1968 concurring opinion, Justice White explained that

[e]ven when a disbarment standard is as unspecific as the one before us, members of a bar can be assumed to know that certain kinds of conduct, generally condemned by responsible men, will be grounds for

97. SeeAttorney Grievance Comm'n v. Martin, 518 A.2d 1050, 1054 (Md. 1987).

98. Id.

99. Id.

100. Gross, supra note 45, at 1455 n.245; see also supra note 47 . Furthermore, in Committee on Professional Ethics v. Durham, the court stated:

The respondent is unable to cite any case in which a provision of the Code of Professional Responsibility has been held to be unenforceably vague, nor has our research uncovered any such instance.... Other jurisdictions which have approached the question of the constitutionality of standards relating to professional conduct, with language similar to [DR 1-102(a)(6)], have upheld the guidelines in the face of vagueness challenges.

279 N.W.2d 280, 282 (lowa 1979) (citing an extensive list of cases).

101. The Supreme Court quoted a United States Court of Appeals for the Sixth Circuit rule containing language strikingly similar to DR 1-102(A)(6). In re Ruffalo, 390 U.S. 544, 554-55 (1968) (White, J., concurring) (quoting Rule 6(3), United States Court of Appeals for the Sixth Circuit). In Zauderer v. Office of Disciplinary Counsel, the court stated:

Given the traditions of the legal profession and an attorney's specialized professional training, there is unquestionably some room for enforcement of standards that might be impermissibly vague in other contexts; an attorney in many instances may properly be punished for "conduct which all responsible attorneys would recognize as improper for a member of the profession."

471 U.S. 626, 666 (1985) (Brennan, J., concurring in part, concurring in the judgment in part, and dissenting in part) (quoting In re Ruffalo, 390 U.S. at 555 (White, J. concurring)). 
disbarment ... includ[ing] conduct which all responsible attorneys would recognize as improper for a member of the profession. ${ }^{102}$

Thus, according to Justice White, similar to the broad concepts of "liberty" in the United States Constitution and "holiness" in Jewish law, broad prohibitions on improper "conduct by attorneys are interpreted to extend to unenumerated conduct, incorporated through the understanding of members of the community-here, members of the legal profession..$^{103}$

102. In re Ruffalo, 390 U.S. at 555 (White, J. concurring).

103. Id. The emphasis on the role of the interpretive community of lawyers in defining the boundaries of ethical behavior is investigated in Susan G. Kupfer, Authentic Legal Practices, 10 GEo. J. LeGAL ETHICS 33 (1996). According to Kupfer, on the individual level, "[t] he lawyer looking to the Model Code or Model Rules to solve practical problems quickly realizes the severe practical limitations: either the matter is explicitly contained in a Disciplinary Rule and his/her conduct is mandated or the lawyer is free to formulate a completely subjective approach to the issue." Id. at 51 (footnotes omitted). She explains, however, in practice that

[t] he individual (the moral self) undertakes the task of formulating, shaping, and building her morality through discursive practice with others. In postmodern thought, practices occur and their meaning is created through interpretation by members of a discrete community. Discursive practice, in which human experience is shaped by and through this interaction, reconstructs meaning from these patterns of experience. Norms and standards in ethical practice, for example, evolve from these acts of interpretation, not through reference to general principles contained in universal codes.

Id. at 63-64 (footnotes omitted); see also id. at 64 n.80 (citing STANLEY FISH, DOING WHAT Comes Naturally: Change, Rhetoric, and the Practice of Theory in Literary and Legal Studies (1989)); STANLEy Fish, Is There a TEXT IN This ClasS?: The Authority of INTERPRETIVE COMMUNITIES (1980)); Kupfer, supra, at 94 n.224 (relying on Stanley Fish for the concept of an "interpretive community, in which one is contingently and historically situated so that one's very construction of knowledge is a product of one's experience").

Although Kupfer further emphasizes that "individual legal actors need to work from their own integrated beliefs because they will find ... that the profession's ethical norms are too vague or unresponsive to the individual lawyer or client's needs," ultimately she acknowledges that "[o]n the other hand, the ethical constraints of community are necessary to temper the wildest and, perhaps, unacceptable individual judgments." Id. at 65 n.86.

The tension Kupfer describes between an individual lawyer's search for ethical truth and the need to rely on the interpretive constraints of the community is inherent more generally in legal reasoning and legal interpretation. Cover describes this tension:

It is the problem of the multiplicity of meaning ... that leads at once to the imperial virtues and the imperial mode of world maintenance. ... Let loose, unfettered, the worlds created would be unstable and sectarian in their social organization, dissociative and incoherent in their discourse, wary and violent in their interactions. The sober imperial mode of world maintenance holds the mirror of critical objectivity to meaning, [and] imposes the discipline of institutional justice upon norms ....

Cover, supra note 62, at 16; see also Owen M. Fiss, Objectivity and Interpretation, 34 STAN. L. REV. 739, 747 (1982) ("[A] hierarchy of authority for resolving disputes that could potentially divide or destroy an interpretive community is one of the distinctive features of legal interpretation."). 
Seventeen years later, without citing Justice White's opinion, the Court as a whole adopted and further refined his approach when interpreting and applying a similar court rule subjecting attorneys to discipline for engaging in "conduct unbecoming a member of the bar of the court." The Court reasoned that "[r]ead in light of the traditional duties imposed on an attorney, it is clear that 'conduct unbecoming a member of the bar' is conduct contrary to professional standards that shows an unfitness to discharge continuing obligations to clients or the courts, or conduct inimical to the administration of justice."

In response to concerns over the application of such a broad standard, the Court continued to focus on historical sources of the traditional obligations of attorneys, concluding that "[m]ore specific guidance is provided by case law, applicable court rules, and 'the lore of the profession' as embodied in codes of professional conduct."106

The Court thus prescribed reliance on both legal precepts, articulated in case law and court rules, and ethical traditions-the "lore" of the legal profession-as sources of "guidance" for identifying the unenumerated substance of the broad prohibition on conduct unbecoming of an attorney. ${ }^{107}$ Like Justice White, the Snyder Court acknowledged the role that traditional conceptions of ethical conduct for lawyers plays in the interpretation of broad ethics rules. ${ }^{108}$

As I have developed elsewhere, this tension is perhaps most pronounced when the search for truth is founded on ethics, as in Kupfer's analysis, or in morality, as in Jewish law. See Levine, supra note 7 at 468-75. Nachmanides explained:

$[E] v e n$ if you think in your heart [the judges of the High Court] are mistaken, and the matter is simple in your eyes ... you must still do as they command you .... [F]or the Torah was given to us in written form and it is known that not all opinions concur on newly arising matters. Disagreements would thus increase and the one Torah would become many Torahs. Scripture, therefore, defined the law that we are to obey [the High Court] ... in whatever they tell us with respect to the interpretation of the Torah....

5 NACHMANIDES, supra note 55, at 206-07 (explicating Deuteronomy 17:11).

104. In re Snyder, 472 U.S. 634, 643-44 (1985) (quoting FED. R. APP. P. 46(b) (1989)).

105. Snyder, 472 U.S. at 645.

106. Id.

107. $I d$.

108. Id. at 644-45; cf. In re Ruffalo, 390 U.S. 544, 555 (1968) (White, J., concurring). As one scholar noted:

Although .... the Court seemed to equate professional lore with the positive disciplinary codes promulgated by state bar associations, the Court also appeared to concede that the competing demands of zealously advocating one's client's cause and advancing the cause of justice must be resolved "in light of the traditional duties imposed on an attorney," which are not neatly captured in the disciplinary codes. 
W. Bradley Wendel, Nonlegal Regulation of the Legal Profession: Social Norms in Professional Communities, 54 VAND. L. REV. 1955, 1963 (2001) (discussing and quoting In re Snyder, 472 U.S. 634, 644-45 (1985)).

The recognition of the significance of both legal precepts and communal traditions in legal interpretation was explored by Robert Cover in his groundbreaking article, Nomos and Narrative. See Cover, supra note 62 . Cover describes a nomos as a "normative universe ... a world of right and wrong, of lawful and unlawful." Id. at 4. Nomos includes a legal tradition comprised of "not only a corpus juris, but also a language and a mythos - narratives in which the corpus juris is located." Id. at 9 . Narratives, in turn, include "the community's ... societal norms, attitudes, and aspirations, which 'bespeak the range of the group's commitments' and 'provide resources for justification, condemnation, and argument by actors within the group, who must struggle to live their law." Levine, supra note 70, at 471 (quoting Cover, supra note 62, at 45).

Cover's framework of "nomos" and "narrative" thus presents yet another conceptual setting for examining hermeneutic similarities in constitutional law, Jewish law, and ethics. Cover's analysis focuses on interpretation of the United States Constitution, in particular in the context of antislavery construction of the Constitution and interpretation of the Free Exercise Clause by members of insular religious communities. See generally Cover, supra note 62. As a number of scholars have observed, and as I have developed at length, "Cover's very conception of 'nomos' and 'narrative' appears influenced by, if not a direct application of, the parallel notions of 'halacha' and 'aggada' in Jewish legal thought." Levine, supra note 70 , at 483; see also id. at 485 n.102 (identifying other scholars).

Likewise, scholars have applied Cover's framework to ethics interpretation:

The idea of community is fundamental to American law. It pervades federal and state constitutions, statutes, and common law doctrines. It also suffuses professional rhetoric and regulation. Most important, it links law to politics, culture, and society.... Applicable to both civil and criminal law fields, the literature assembles a wide-ranging collection of community norms and narratives.

Anthony V. Alfieri, Prosecuting Violence/Reconstructing Community, 52 STAN. L. REV. 809, 819 (2000) (footnotes omitted); Koniak, supra note 33, at 1390 n.1 ("This Article uses Robert Cover's rich and original vision of law, which he articulated most fully in [Nomos and Narrative] . . . as a means of understanding the law governing lawyers."); id. at 1392 ("This Article examines the profession's nomos-its law-and how it contrasts, competes and coexists with the state's law governing lawyers."'); W. Bradley Wendel, Professional Roles and Moral Agency, 89 GEo. L.J. 667, 685 (2001) (book review)(“An ethical principle does not have meaning in the abstract, but takes its content from the normative understanding - the nomos in Robert Cover's term-of the community which adheres to the principle" (footnotes omitted)); W. Bradley Wendel, Value Pluralism in Legal Ethics, 78 WASH. U. L.Q. 113, 118 (2000) ("The community's nomos-the justificatory narrative that locates, constitutes, and gives meaning to the social institution of lawyering-is itself the criterion for ranking the competing professional values." (footnotes omitted)); see also Kupfer, supra note 103 at 65 $\mathrm{n} .86$ (noting that the ethical constraints of community are needed to guide individual moral judgments); Thomas L. Shaffer, Legal Ethics and Jurisprudence from Within Religious Congregations, 76 NOTRE DAME L. REV. 961, 963 (2001) (suggesting that lawyers can find answers to ethical dilemmas in the context of moral concepts "better than in "professional" committees that propound and interpret ethical rules").

The idea that there exist communal narratives and traditions for lawyers has been explored by some of the most prominent and influential ethics scholars. See, e.g., MONROE H. FREEDMAN, UNDERSTANDING LAWYERS' ETHICS 75-76 (1990) (describing the actions of Sir Marshall Hall and Lord Erskine as "incidents [that] ha[ve] come down in our professional lore from the tradition of the English barrister" and that have "been cited as representing the ideal of an independent bar"); THOMAS L. SHAFFER, FAITH AND THE PROFESSIONS (1987); Hazard, supra note 1, at 1243-44 (describing a "narrative of the American legal profession 
In considering challenges to provisions prohibiting "conduct that adversely reflects on [the attorney's] fitness to practice law,"109 courts have similarly described and applied the notion that members of the legal profession are expected to possess an understanding of what conduct is improper and unethical, even if such conduct is not specifically enumerated in an ethics code. The New York Court of Appeals, citing Justice White's concurrence ${ }^{110}$ rejected arguments for "an absolute prohibition on broad standards" such as DR 1102(A)(6)." Instead, the court adopted the "guiding principle" of "whether a reasonable attorney, familiar with the Code and its ethical strictures, would have notice of what conduct is proscribed."112

[as] convey[ing] a ... clear ideal ... of the fearless advocate who champions a client threatened with loss of life and liberty by government oppression" and describing the process through which this "basic narrative has been sustained over two centuries"); Koniak, supra, at 1447-60 (describing the "central and recurring theme in the profession's narratives portray[ing] the lawyer as champion, defending the client's life and liberty against the government, which is portrayed as oppressor, willing, ready and able to use its power to destroy the individual and the values society holds dear"); $i d$. at 1448, $1450 \mathrm{n} .263$ (observing that "[t]he story has many versions"); Carrie Menkel-Meadow, Foreword: Telling Stories in School: Using Case Studies and Stories to Teach Legal Ethics, 69 FordHAM L. Rev. 787 (2000); Thomas L. Shaffer, Lawyers as Prophets, Prophets as Lawyers, at 1-3 (unpublished manuscript, on file with author) (describing role of tradition and mentors in practice of law and identifying John Adams, Andrew Hamilton, army lawyers who defended General Yamashita, and Thomas More as his own mentors); see also Leslie E. Gerber, Can Lawyers Be Saved? The Theological Legal Ethics of Thomas Shaffer, 10 J.L. \& ReLIGION 347, 353 (1993-94) (describing Shaffer's pioneering work as "narrative legal ethics").

109. MODEL CODE OF PROF'L RESPONSIBILTTY DR I-102(A)(6) (1981).

110. See supra notes 101-103 and accompanying text.

111. In re Holtzman, 577 N.E.2d 30, 33 (N.Y. 1991). The New York fitness to practice provision, formerly codified as NEW YORK CODE OF PROF'L RESPONSIBILITY DR 1-102(A)(6), is currently DR 1-102(A)(7) (2002).

Although the precise wording of then DR 1-102(A)(6) is different from that of the "conduct unbecoming" court rule addressed by Justice White, the New York court apparently found the substance of the ethics rule sufficiently like that of the court rule for the purpose of both its analysis of DR 1-102(A)(6) and its more general endorsement of broad ethics provisions. See In re Holtzman, 577 N.E.2d at 33.

In a similar vein, Wolfram groups his negative depiction of broad ethics provisions together with his criticism of Federal Rule of Appellate Procedure 46(c), the "conduct unbecoming" provision addressed and upheld by the United States Supreme Court in In re Snyder, 472 U.S. 634, 643-44 (1985). In fact, following his discussion of what is, in his view, the improperly broad nature of DR 1-102(A)(5) and DR 1-102(A)(6) of the Model Code and Rule 8.4(d) of the Model Rules, Wolfram writes that "[u]ltimate breadth is achieved in [Federal] Rule [of Appellate Procedure] 46(c)." WoLFRAM, supra note 3, at 88.

If Wolfram's framework is adopted, it would seem that, to the extent that justifications for and methods of interpretation of Rule 46, such as that offered through the Court's analysis in In re Snyder, prove convincing such analysis should likewise satisfy concerns about the application of the ethics provisions that, in Wolfram's stated view, are not as broad as Rule 46. See supra notes 104-108 and accompanying text.

112. In re Holtzman, 577 N.E.2d at 48; see also State ex rel. Neb. State Bar Ass'n v. Kirshen, 441 N.W.2d 161, 168 (Neb. 1989) ("A reasonable attorney would understand that 
Applying this principle, an intermediate New York State court rejected an attorney's argument that he should not be sanctioned under the New York Code's "fitness to practice law" provision ${ }^{113}$ for "violating a standard of conduct that had never before been announced."114 The court held that discipline was appropriate because, although the case was one of first impression, "a reasonable attorney would have been on notice that revealing sensitive information about client matters to reporters could be held to reflect adversely on his or her fitness as a lawyer."1's Thus the court upheld the broad rule and, through an analysis of the ethical understandings of the reasonable attorney, interpreted the rule as a source of an unenumerated obligation that had never before been identified by the court. ${ }^{116}$

Other courts have offered similar grounds for rejecting challenges to the application of ethics provisions modeled after DR 1-102(A)(6). The Colorado Supreme Court emphasized that ethics rules are written for lawyers, not for the public:

Since a disciplinary rule is promulgated for the purpose of guiding lawyers in their professional conduct, and is not directed to the public at large, the central consideration in resolving a vagueness challenge

this type of conduct is prohibited and adversely reflects on his fitness to practice law."); Comm. on Prof'l Ethics v. Durham, 279 N.W.2d 280, 284 (Iowa 1979) (adopting standard of "whether a 'reasonable attorney' would understand certain conduct to be prohibited").

113. NEW YORK CODE OF PROF'L RESPONSIBILITY DR 1-102(A)(7) (2002).

114. In re Holley, 729 N.Y.S.2d 128, 132 (App. Div. 2001).

115. Id.

116. Id. Indeed, under this analysis, it might appear less necessary to enumerate conduct in ethics codes that is more obviously improper in light of the traditions and understandings of the profession. The absence of enumeration and/or case law addressing such conduct thus may be considered more a function of the lack of necessity of such authority than a reflection of the possibility that such conduct is not ethically prohibited. See Grievance Comm. v. Rottner, 203 A.2d 82, 85 (Conn. 1964). The Rottner Court held:

The almost complete absence of authority governing the situation where, as in the present case, the lawyer is still representing the client whom he sues clearly indicates to us that the common understanding and the common conscience of the bar is in accord with our holding that such a suit constitutes a reprehensible breach of loyalty and a violation of the preamble to the Canons of Professional Ethics. This determination is sufficient to support the judgment and to render unnecessary a discussion of the specific canons which the court found were violated by the defendants.

Id. at 85 . But see In re Gadbois, 786 A.2d 393, 400 (Vt. 2001) (quoting RESTATEMENT (THIRD) OF THE LAW GOVERNiNG LAWYERS $\S 5 \mathrm{cmt}$. c) (adhering to the comment of the Restatement that "a specific lawyer-code provision that states the elements of an offense should not, in effect, be extended beyond its stated terms through supplemental application of a general provision to conduct that is similar to but falls outside of the explicitly stated ground for a violation"). 
should be whether the nature of the proscribed conduct encompassed by the rule is readily understandable to a licensed lawyer. ${ }^{117}$

117. People v. Morley, 725 P.2d 510, 516 (Colo. 1986) (en banc); cf. Comm. on Prof'l Ethics v. Durham, 279 N.W.2d 280, 284 (lowa 1979) (rejecting a challenge to broad ethics provisions in part because "the Code of Professional Responsibility was written for lawyers by lawyers"); Koniak; supra note 32, at 1393 n.15 (citing Robert W. Gordon, The Independence of Lawyers, 68 B.U. L. REV. 1, 10 (1988) (referring to "scholars of the profession, who understand the importance of the substantial heterogeneity in background, substance of work and work-setting of the modern bar, [but] have also described and accepted the existence of a core of shared normative understandings"); Deborah L. Rhode, Ethical Perspectives on Legal Practice, 37 STAN. L. REv. 589, 595-605 (1985)). But see Damtoft, supra note 48, at 1407-08 (distinguishing Durham from Parker v. Levy, 4 I 7 U.S. 733 (1974), which upheld 10 U.S.C. $\$ 933$ (1964), a provision of the Uniform Code of Military Justice prohibiting "conduct unbecoming an officer and gentleman"). Damtoft also argued that "[ $t$ ]he law, training, and traditions of ethics in the civilian legal practice . . . are not as clearly developed as the military standards of behavior" and, "[t]herefore, the penumbra of clearly prohibited behavior under a broad standard for attorney conduct is considerably narrower than it is in a military context, and as a result, the Iowa Supreme Court's reliance on collateral interpretations of the provisions for clarification may not be well founded." Id.

Johnston compares the Code of Proféssional Responsibility to the Military Code:

[T] he legal profession is sufficiently cohesive and differentiated from society by its own history and traditions to give content to seemingly imprecise professional rules and to justify the application of a more lenient standard of vagueness to those rules, along the lines of that applied to the Military Code in Parker v. Levy. This rationale has been adopted by some courts, but for several reasons it appears misplaced.... [First,] it is less likely in the legal context than in the military context that the interpretations of [the] code[] will be uniform. ... [Second,] the myriad interpretations of the ABA Code by various state and federal courts cannot carry the same authority as the years of narrowing construction of the Code of Military Justice by the United States Court of Military Appeals. ... [Third, the legal profession is simply not as homogeneous, traditional and specialized in function as the military. ... [Finally,] the Military Code provision was upheld under a diluted standard of vagueness review because the special responsibilities of servicemen in defense of the country, and the overriding need for discipline and obedience in the armed forces justify more limited constitutional rights for servicemen than for civilians.

Martha E. Johnston, Comment, $A B A$ Code of Professional Responsibility: Void for Vagueness?, 57 N.C. L. REv. 671, 687-88 (1979); see also Painter, supra note 6, at 722 n.286 ("II]t is possible that standards would be preferable to defined rules, if courts and agencies would build valuable precedent interpreting the standards as they have in contract and corporate law. A number of factors, however, distinguish the law governing lawyers from contract and corporate law."). Zacharias argues that

professional codes must be evaluated differently than ordinary legislation and administrative schemes-even those that include legal "standards" as flexible as the standards in the codes. Flexible legal standards ordinarily rest on a premise that courts or some other lawmaking body will flesh out the standards and enforce more specific guidelines for behavior. ... In contrast, professional code provisions rarely are fleshed out; clarifying ethics opinions are scarce, ad hoc, and generally inaccessible.

Zacharias, supra note 4, at 237-38; see also id. at 241 (citing scholarship in support of the proposition that some code provisions "set guidelines for conduct about which the rulemakers 
As to the argument that "DR 1-102(A)(6) does not articulate what constitutes conduct affecting a lawyer's fitness to practice law,",118 the Connecticut Supreme Court responded that "[l]awyers are chargeable for deviations from the codes governing their conduct, even though the application of the canons to particular circumstances may not be readily apparent.",119

Perhaps the Vermont Supreme Court's analysis best reflects the approach of courts that have examined the norms and traditions of the legal profession in interpreting broad fitness to practice provisions as a source for the articulation of unenumerated ethical obligations. Although it acknowledged that the "generality of the phrase" in the fitness to practice rule "does make the rule susceptible to varying subjective interpretations," the court concluded that "the everyday realities of the profession and its overall code of conduct provide definition for this type of phrase and thus give adequate notice of which behavior constitutes proscribed conduct. ${ }^{320}$

2. DR 1-102(A)(5); Rule 8.4(d): "Conduct That Is Prejudicial to the Administration of Justice"

Not surprisingly, similar controversy and debate have ensued surrounding the broad ethics provision, codified in both the Model Code and the Model Rules, prohibiting "conduct that is prejudicial to the administration of justice."'12l This provision has been criticized because of the concern among some scholars that "[a]rbitrary enforcement can be expected if, for example, there is no consensus on what types of conduct are included."122 Some courts have expressed a similar dissatisfaction with the broad nature of the rule and its application to unenumerated areas of obligation. Typical of this view is the argument of one judge who, on the grounds that the language of the rule "does not give ... guidance" to "[c]areful lawyers," dissented

do not share, and do not expect to attain, a consensus"); id at 276 (asserting that "a highly generalized provision cannot assist the courts in filling gaps in the substantive law").

118. Statewide Grievance Comm. v. Rozbicki, 595 A.2d 819, 825 (Conn. 1991).

119. Id. at 825 (quoting Patterson v. Council on Probate Judicial Conduct, 577 A.2d 701,708 (Conn. 1990) (citing Grievance Comm. v. Rottner, 203 A.2d 82, 84-85 (Conn. 1964))).

120. In re llluzzi, 632 A.2d 346, 349 (Vt. 1993) (quoting $A B A B N A$ Lawyer's Manual on Professional Conduct, 101:1001 (1987)).

121. MODEL CODE OF PROF'L RESPONSEILITY DR 1-102(A)(5) (1981); MODEL RULES OF PROF'L RESPONSIBILITY R. 8.4(d) (1983).

122. Johnston, supra note 117 , at 685 . 
from the majority's "exten[sion of] the rule for the first time" to a new set of facts. ${ }^{123}$

Nevertheless, similar to the approach of courts toward fitness to practice provisions, "most courts have upheld [prejudicial to the administration of justice] provisions against constitutional attacks on the grounds of vagueness and overbreadth.", ${ }^{24}$ Thus a more typical view of the rule may be that of the Court of Appeals of Maryland, which rejected an attorney's argument that the rule did not provide him sufficient notice. ${ }^{125}$ The court bluntly responded that the attorney "could not be more incorrect."126 As the court explained, "[i]t strains credulity to say that, merely because this Court had never previously addressed similar circumstances, an attorney with Goldsborough's experience was not 'on notice' that the conduct alleged by Bar Counsel could violate the Rules of Professional Conduct."127

Indeed, as in the interpretation of fitness to practice provisions, many courts emphasize that because ethics codes are written for lawyers, the interpretation of prejudicial to the administration of justice provisions depends in part on the understanding of the professional legal community. ${ }^{128}$ Moreover, like the constitutional guarantee of liberty and the biblical command to be holy, this prohibition in ethics codes is applied to unenumerated situations on the basis of an

123. In re Masters, 438 N.E.2d 187, 197 (dll. 1982) (Simon, J., dissenting); cf. In re Discipline of Two Attorneys, 660 N.E.2d 1093, 1099 (Mass. 1996) (stating that "[t]he better course, where possible, is to deal with alleged professional misconduct under specific rules ... rather than to invoke the general language of DR 1-102(A)(5)").

124. Gross, supra note 45 , at 1455 n.245 (citing sources).

125. Attorney Grievance Comm'n v. Goldsborough, 624 A.2d 503, 511 (Md. 1993).

126. Id.

127. Id.

128. See, e.g., id. at 510 (holding that Rule $8.4(\mathrm{~d})$ "is sufficiently definite to pass constitutional muster [because] [t] he Rule applies only to lawyers, who are professionals and have the benefit of guidance provided by case law, court rules and the "lore of the profession"" (internal quotations and citations omitted)); Howell v. State Bar, 843 F.2d 205, 208 (5th Cir. 1988) (quoting inter alia, In re Snyder, 472 U.S. 634, 645 (1985)) (finding that "[t]he traditional test for vagueness in regulatory prohibitions is whether "they are set out in terms that the ordinary person exercising ordinary common sense can sufficiently understand and comply with, without sacrifice to the public interest"" and that, therefore, "[t]he particular context in which a regulation is promulgated ... is all important" and noting that DR 1-102(A)(5) "applies only to lawyers, who are professionals and have the benefit of guidance provided by case law, court rules and the "lore of the profession."'); In reKeiler, 380 A.2d 119, 126 (D.C. 1977) (noting that DR 1-102(A)(5) "was written by and for lawyers" and explaining that "[ $t]$ he language of a rule setting guidelines for members of the bar need not meet the precise standards of clarity that might be required of rules of conduct for laymen."). 
examination of tradition that lends content and meaning to the broad rule. ${ }^{129}$

Alternatively, some courts applying prejudicial to the administration of justice provisions have employed an interpretive methodology more closely resembling the interpretation of constitutional conceptions of privacy and the biblical command to do the just and the good. ${ }^{130}$ Rather than turning to general notions of communal tradition, these courts have identified unenumerated conduct prejudicial to the administration of justice by looking to the substance of and extending the contours of enumerated ethics rules.

Applying this methodology, the Superior Court of Rhode Island concluded that a lawyer is prohibited from appearing before a judge to

129. See, e.g., Howell, $843 \mathrm{~F} .2 \mathrm{~d}$ at 206. The court in Howel/ relied on the tradition of the bench and bar to provide a context for DR 1-205(a)(5) by recognizing that

[t] here was nothing startlingly innovative in DR $1-102(A)(5)$ 's contents. Since the early days of English common law, it has been widely recognized that courts possess the inherent power to regulate the conduct of attorneys who practice before them and to discipline or disbar such of those attorneys as are guilty of unprofessional conduct.

Id. (citing, inter alia, In re Snyder, 472 U.S. 634, 643 (1985)). Emphasizing the special role attorneys play in the justice system, the court noted that such a position has always incorporated a corresponding obligation:

Case after case can be cited in support of the general proposition that, as officers of the court, attorneys owe a duty to the court that far exceeds that of lay citizens....

The Texas cases which both antedated and followed the adoption of DR 1$102(A)(5)$ demonstrate quite clearly that the State's primary concern consistently has been with the obligation of lawyers in their quasi-official capacity as "assistants to the court."

Id. at 207; In re Hinds, 449 A.2d 483, 497-98 (N.J. 1982) (citing, inter alia, In re Ruffalo, 390 U.S. 544 (1968)) (noting that " $D R 1-102(A)(5)$ is framed in broad language and gives the appearance of an aspirational standard, rather than a disciplinary rule [but that] [c]ourts have held that a broad disciplinary rule may acquire constitutional certitude when examined in light of traditions in the profession and established patterns of application"); Keiler, 380 A.2d at 126 ("The language of the rule is clear. It is not a new standard but a restatement of a previously existing one."); Office of Disciplinary Counsel v. Campbell, 345 A.2d 616, 621-22 (Pa. 1975). While enforcing a broad ethical proscription, the Pennsylvania Supreme Court declined to address the outer limits of the proscriptions and noted that the attorney should have known that he was violating them:

We need not today define with exactitude the boundaries of the conduct proscribed by Disciplinary Rules 1-102(A)(5) and 1-102(A)(6). Certainly respondent's activities were within those bounds and respondent knew or should have known that such was the case. Since respondent had fair notice that his course of conduct was prohibited by the Code of Professional Responsibility, he cannot claim to have been prejudiced by the arguable vagueness of the Disciplinary Rules when applied to other hypothetical situations.

Id. at 622 .

130. See supra notes $74-82$ and accompanying text. 
whom the lawyer has loaned money. ${ }^{13 !}$ The court acknowledged that there was no such prohibition among the many enumerated ethics rules implicated when an attorney lends money to a judge. ${ }^{132}$ Nevertheless, the court derived this prohibition through an interpretive methodology involving an examination of the principles underlying the enumerated rules, in conjunction with the identification of a broader source of unenumerated obligation. ${ }^{133}$ Specifically, the court relied on the broad provision against "engag[ing] in conduct that is prejudicial to the administration of justice" to provide a conceptual basis for the unenumerated prohibition. ${ }^{134}$ The court found that

[t]his sweeping edict is not only broad enough to encompass the specific prohibition against lawyers making loans to judges that is encompassed elsewhere in the rules but also implicitly forbids a lawyer from appearing before a judge to whom he or she has loaned money, particularly where the existence of the loan has not been disclosed. ${ }^{135}$

131. Hurley v. Fuyat, C.A. No. 92-5082, 1994 WL 930891 , at *7 (R.I. Super. Jan. 5, 1994) (unpublished opinion).

132. See id. (stating that "[b]oth the old and the new rules explicitly prohibit a lawyer from making loans to a judge"). The court cited and described the following:

DR 7-110 (prohibiting a lawyer from giving or lending anything of value to a judge); Rule 3.5 (prohibiting a lawyer from seeking to influence a judge by means prohibited by law); Rule 8.4(f) (forbidding a lawyer from knowingly assisting a judge in conduct that is a violation of applicable rules of judicial conduct); Rule 21, Canons of Judicial Ethics (prohibiting a judge from receiving loans from litigants, lawyers or others whose interests are likely to be submitted to the judge for judgment). If a judge wrongfully solicits a loan from a lawyer, the lawyer is obligated to refuse the request and report the judicial misconduct to the appropriate disciplinary authorities. [Additionally,] see ... DR 1-103 (requiring a lawyer possessing knowledge of another lawyer's conduct that is prejudicial to the administration of justice to report the violative conduct to a tribunal or other authority empowered to investigate or act upon such violation); Rule 8.3(a)(b) (requiring lawyers to report to the appropriate professional authorities the professional misconduct of judges and other lawyers).

Id. (citations omitted).

133. See id.

134. Id. (alteration in original) (quoting DR 1-102(A)(5); R. 8.4(d)).

135. Id.; cf. In re Rinella, 677 N.E.2d 909, 914 (Ill. 1997) (finding a violation of DR 1$102(\mathrm{~A})(5)$, "reject[ing] respondent's contention that attorney misconduct is sanctionable only when it is specifically proscribed by a disciplinary rule" and concluding that "we do not believe that respondent, or any other member of the bar, could reasonably have considered the conduct involved here to be acceptable behavior under the rules governing the legal profession"); $i d$. at 916-17 (Freeman, J., concurring in part and dissenting in part) ("No rule need have existed to inform respondent that his conduct, which was so obviously improper, was violative of the rules of professional conduct. ... Furthermore ... implicit in the Code is that every attomey, in the exercise of professional judgment, will conduct him or herself in a manner which will not potentially compromise the attorney-client relationship."). The Minnesota Supreme Court commented on the Constitutionality of Disciplinary Rules 1$102(\mathrm{~A})(5)$ and (6): 


\section{Canon 9: "Avoid[ing] Even the Appearance of Professional Impropriety"}

Perhaps the broadest ethics provision serving as a source for unenumerated ethical obligations, and the one arousing the most criticism among scholars and courts, is the command, codified in Canon 9 of the Model Code, to "avoid even the appearance of professional impropriety.136 Though he may have leveled the sharpest attack on the appearance-of-impropriety standard, ${ }^{137}$ Wolfram is far from its only critic among leading ethics scholars. ${ }^{138}$ According to

Disciplinary Rules 1-102(A)(5) and (6) do no more than reflect the fundamental principle of professional responsibility that an attorney, as an officer of the court, has a duty to deal fairly with the court and the client. This duty embraces all of the ethical strictures of the code of professional responsibility. Read in conjunction with the other disciplinary rules, we conclude, as have other courts, that these phrases are sufficiently well defined to satisfy due process.

In re N.P., 361 N.W.2d 386, 395 (Minn. 1985).

136. MOdEL CODE OF PROF'L Responsibiluty Canon 9 (1981).

137. See supra notes $34-41$ and accompanying text.

138. See supra note 41 . It is not clear why a nearly identical provision regulating the conduct of judges has not been subjected to the same criticism as Canon 9. See CODE of JUDICIAL CONDUCT Canon 2 (1990) ("A judge shall avoid impropriety and the appearance of impropriety in all of the judge's activities."); see also id. Canon 3E(1) ("A judge shall disqualify himself or herself in a proceeding in which the judge's impartiality might reasonably be questioned ...."); 28 U.S.C. $\S 455$ (a) (2002) ("Any justice, judge, or magistrate judge of the United States shall disqualify himself in any proceeding in which his impartiality might reasonably be questioned."); Leslie W. Abramson, Appearance of Impropriety: Deciding When a Judge's Impartiality "Might Reasonably Be Questioned", 14 GEO. J. LEGAL ETHICS 55, 55 (2000) ("The Codes of Judicial Conduct refer throughout to the appearance of impropriety."). See generally Roberta K. Flowers, What You See Is What You Get: Applying the Appearance of Impropriety Standard to Prosecutors, 63 Mo. L. Rev. 699, 703 (1998) (contrasting the Model Rules of Professional Conduct and the Judicial Code of Conduct). Professor Gillers, for example, a harsh critic of the appearance of impropriety standard for lawyers, see text infra, notes the "interesting distinction between ethics codes for lawyers and those for judges." GILLERS, supra note 41 , at 632 . Specifically, "[w]hereas lawyer codes have come to disfavor the 'appearance of impropriety' as a standard for evaluating a private lawyer's conduct ..., judicial codes continue to be sensitive to appearances." Id. (cross-reference omitted). Gillers concludes with a question to the reader: "Why does it make sense, for surely it does, to adhere to an appearance standard for judges but not private lawyers?" Id. at 633 . Gillers may have considered the answer to this question sufficiently self-apparent and/or he may have decided, understandably, that a chapter on judges in a casebook on the law governing lawyers is not the place for a more lengthy discussion of the issue he raised. Yet it seems that, under a closer analysis, the issue does not lend itself to obvious solutions.

One possible answer might lie in a theory that distinguishes between "differing roles played by lawyer and judge." Flowers, supra, at 724 . Under such a theory, because the lawyer "is a conduit between the individual and the system ... the Model Rules regulate the relationship between the attorney and the client. By contrast ... the judge serves both a functional and symbolic role." Id. at 725 . Thus, the theory concludes, the appearance of impropriety standard "requires judges to consider the effect of both their conduct and their 
Professor Stephen Gillers, for example, "[j]udicial resort to the 'appearance of impropriety' test bespoke the [Model] Code's inadequacy as a document on which to build a mature jurisprudence of legal ethics.", Ins Indeed, Gillers notes that "[e]ven the ABA disowned [the provision]," both by calling it, in an ethics opinion, " too vague a phrase to be useful"' and by omitting the standard from the Model Rules. ${ }^{140}$

perceived conduct on the public's impression of the system." Id; cf. STEPHEN GILLERS, Teacher's Manual, Regulation of Lawyers: Problems of Law and Ethics 195 (5th ed. 1998) (answering that "judges (unlike most lawyers) wield public power, which requires greater public confidence in what they do and how they do it").

Despite the appeal of this answer, however, questions still remain. First, as Professor Monroe Freedman has argued,

[1]ike judges ... lawyers are an integral part of the administration of justice, and it is essential that fair-minded people have no reasonable grounds to suspect that the administration of justice is being impaired by the improper conduct of lawyers. The appearance of impropriety is, therefore, an appropriate concern of lawyers' ethics.

FREEDMAN, supra note 108, at 177.

Second, and more directly relevant to the consideration of issues of interpretive methodology, this answer does not explain why the appearance of impropriety standard as applied to judges is any less vague than the same standard applied to lawyers. It would seem, rather, that the justification for and validity of such a broad provision in a code of judicial ethics should likewise apply to lawyers' ethics codes.

Indeed, the Commentary to Canon 2 offers a nearly identical justification to that which courts and scholars have offered for broad provisions in lawyers' ethics codes: "Because it is not practicable to list all prohibited acts, the proscription is necessarily cast in general terms that extend to conduct by judges that is harmful although not specifically mentioned in the Code." Code OF JUdicial Conduct Canon 2(A) cmt. (1990); cf. supra notes 48-50 and accompanying text.

In the context of this Article, it is notable that one leading ethics scholar referred to the appearance of impropriety standard for judges as the "basic rule of the Code of Conduct, the one to which all other rules are mere commentary." Andrew L. Kaufman, Judicial Ethics: The Less-Often Asked Questions, 64 WASH. L. REv. 851, 854 (1989). This phraseology alludes to Talmudic descriptions of the command "love your neighbor as yourself", Leviticus 19:18, as "a fundamental rule in the Torah," JERUSALEM TALMUD, Nedarim 9:4, to which "the rest of the Torah is commentary," TALMUD BAVLI, Shabbath 31a. The comparison between the appearance of impropriety standard and the command to love one's neighbor is significant, as these two broad rules may share a common interpretive methodology. See infra notes 156-175 and accompanying text.

139. GRLERS, supra note 41 , at 358 .

140. Id. (quoting ABA. Comm. on Ethics and Prof'1 Responsibility, Formal Op. 342 (1975)); MODEL RULES OF PROF'L CONDUCr R. $1.9 \mathrm{cmt}$. (1983) (stating that "since 'impropriety' is undefined, the term 'appearance of impropriety' is question-begging [and that, therefore,] the problem of imputed disqualification cannot be properly resolved ... by the very general concept of appearance of impropriety"); see also Lee E. Hejmanowski, Note, An Ethical Treatment of Attorneys' Personal Conflicts of Interest, 66 S. CAL. L. REV. 881, 897 (1993) (stating that "courts and legal conduct rules renounced that standard on the grounds that, standing alone, it was inherently vague"). 
In addition to scholarly criticism, like other broad ethics provisions, the prohibition against the appearance of impropriety has faced opposition from courts reluctant to rely on such a broad standard as a source of unenumerated ethical obligations. The United States Court of Appeals for the Second Circuit "caution[ed] ... that Canon 9, though there are occasions when it should be applied, should not be used promiscuously as a convenient tool for disqualification when the facts simply do not fit within the rubric of other specific ethical and disciplinary rules."'t4 Other judges have refused to apply the appearance of impropriety standard because, like Gillers, they have noted its absence from the Model Rules. ${ }^{142}$

Nevertheless, despite the criticism it has sustained, the appearances of impropriety standard stands, alongside DR 1102(A)(6) and DR 1-102(A)(5)/Model Rule 8.4(d), as yet a third broad ethics provision that many courts have applied and interpreted as a source of unenumerated ethical obligations. ${ }^{143}$ In fact, of these three

141. Int'l Elecs. Corp. v. Flanzer, 527 F.2d 1288, 1295 (2d Cir. 1975); see also Bd. of Educ. v. Nyquist, 590 F.2d 1241, 1247 (2d Cir. 1979) ("We believe that when there is no claim that the trial will be tainted, appearance of impropriety is simply too slender a reed on which to rest a disqualification order except in the rarest cases."); of. Bruce A. Green, Conflicts of Interest in Legal Representation: Should the Appearance of Impropriety Rule Be Eliminated in New Jersey-or Revived Everywhere E/se?, 28 SETON HALL L. REV. 315, 320-25 (1997) (discussing the history and evolution of the appearance of impropriety rule in New Jersey). Professor Green argues that

[a]s presently conceived, the overriding concern of the appearance of impropriety test has evolved from its original focus on confidence in government to the more nebulous concept of confidence in the bar. This has led to the unnecessary reliance upon an ad hoc appearance of impropriety analysis, even in those cases that might be decided by other, more precise, and less restrictive rules.

Id. at 344-45; Kaufman, supra note 138. Describing his approach to the appearance of impropriety rule, Professor Kaufman explains:

I usually tell my students that most of the time the phrase "appearance of impropriety" is a substitute for thought and close analysis. In most cases, what is usually at stake is a lawyer's responsibility to a particular person, and a court ought to be able to supply a more specific reason for disapproving lawyers' conduct than something called the appearance of impropriety.

Id. at 854 .

142. See, e.g., First Am. Carriers, Inc. v. Kroger Co., 787 S.W.2d 669, 674 (Ark. 1990) (Bristow, J., dissenting) (observing that "appearance of impropriety ... is a familiar and oftquoted phrase but does not actually appear in the language of the Model Rules of Professional Conduct as adopted by this Court").

143. A number of these courts have expressed their abiding faith in the continued viability of the appearance of impropriety standard in spite of its omission from the Model Rules. See, e.g., Lovell v. Winchester, 941 S.W.2d 466, 468 (Ky. 1997) ("Even though the comment to Rule 1.9 specifically rejects the 'appearance of impropriety' standard ... the appearance of impropriety is still a useful guide for ethical decisions."); Cardona v. Gen. Motors Corp., 942 F. Supp. 968, 975 (D.N.J. 1996) (describing importance of the "much 
rules, it appears that the courts' approach to the appearance of impropriety. provision may offer the fullest range of interpretive methodologies parallel to those used to identify unenumerated principles in constitutional law and Jewish law.

As in the interpretation of the other broad ethics provisions, some courts have employed an interpretive methodology similar to that used

maligned" appearance of impropriety doctrine); Heringer v. Haskell, 536 N.W.2d 362, 366 (N.D. 1995) (acknowledging argument that "the Rules of Professional Conduct have abandoned the 'appearance of impropriety' standard that was the basis for the old Canons and Disciplinary Rules, in favor of a more flexible, fact-based approach," but concluding and citing cases to support the proposition that "[a]lthough the new Rules do not use the language, the 'appearance of impropriety' standard has not been wholly abandoned in spirit"). A Wisconsin Court described the role of the appearance of impropriety test after the adoption of the ABA Model Rules of Professional Responsibility:

Prior to 1987, the Wisconsin Code of Professional Responsibility provided that attorneys "should avoid even the appearance of professional impropriety." This rule embodied the substance of Canon 9 of the ABA Code of Professional Responsibility. In 1987, Wisconsin adopted the ABA Model Rules of Professional Responsibility, which omit the "appearance of impropriety" language. Instead, the code enumerates specific prohibited conflicts of interest. The change in language was motivated by the fact that the term "impropriety" is not specifically defined.

The obligation to avoid appearances of impropriety is nonetheless implicit in the new Wisconsin Rules of Professional Conduct.

State v. Retzlaff, 490 N.W.2d 750, 752 (Wis. Ct. App. 1992) (citations omitted); MMR/Wallace Power \& Indus. v. Thames Assocs., 764 F. Supp. 712, 718 n.9 (D. Conn. 1991) (observing "[t]hat a lawyer is ethically obligated to avoid "even the appearance of impropriety' is embodied in Canon 9 of the Code of Professional Responsibility," and stating that "[a]lthough the Code has not been formally adopted in Connecticut, 'its salutary provisions have consistently been relied upon by the courts ... in evaluating the ethical conduct of attorneys," and noting that "prior to its adoption of the [Connecticut] Rules [of Professional Conduct], this court recognized the Code of Professional Responsibility of the American Bar Association as expressing the standards of professional conduct expected of lawyers" (citations omitted)); First Am. Carriers, 787 S. W.2d at 671-72 (noting that "Canon 9 was a part of the ABA Code of Professional Responsibility and the exact language is not in the Model Rules of Professional Conduct adopted by this court," but concluding that "[t]he fact that Canon 9 is not in the Model Rules does not mean that lawyers no longer have to avoid the appearance of impropriety" because, "[w]hile Canon 9 is not expressly adopted by the Model Rules, the principle applies because its meaning pervades the Rules and embodies their spirit"); Turbin v. Super. Ct., 797 P.2d 734, 738 (Ariz. Ct. App. 1990) ("We hold today that the appearance of impropriety ... still has a definite place in the balancing test the trial court must apply in resolving the question of disqualification,"); Gomez v. Super. Ct., 717 P.2d 902, 904 (Ariz. 1986) (finding that "'appearance of impropriety,' however weakened by case law and its omission in the new Rules of Professional Conduct, survives as a part of conflict of interest"); Pantry Pride, Inc. v. Finley, Kumble, Wagner, Heine, Underberg \& Casey, 697 F.2d 524, 530 (3d Cir. 1982) (citing Proposed Final Draft, ABA Model Rules of Professional Conduct 40 (June 30, 1982) (omitting Canon 9 as overbroad and questionbegging)) ("Although the appearance of impropriety standard has been criticized recently, ... Canon 9 is still the law in this circuit." (citation omitted)); In re Hinds, 449 A.2d 483, 498 (N.J. 1982) (referring to "[t]he legal profession's cardinal ethical edict-ro avoid even the appearance of impropriety" (internal quotations omitted)). 
in interpreting the constitutional guarantee of liberty and the biblical command to be holy. ${ }^{144}$. These courts have looked to history and traditional understandings of the role and responsibilities of lawyers as a means for identifying unenumerated ethical obligations based on the appearance of impropriety standard. For example, applying the standard to a 1996 "side-switching attorney" case, one court rejected the "frequently ... made" argument that appearance of impropriety "embodies 'an arbitrary and vague standard.", 145

Instead, the court emphasized the importance of applying and enforcing the appearance of impropriety standard to "engender, protect and preserve the trust and confidence of clients," particularly when an attorney has "chang[ed] sides."146 "At the heart" of such a scenario, according to the court, "is the suspicion that by changing sides, the attorney has breached a duty of fidelity and loyalty to a former client, a client who had freely shared with the attorney secrets and confidences with the expectation that they would be disclosed to no one else."147 Thus, a crucial aspect of the court's analysis relied on what it viewed as traditionally understood - though largely unenumerated-aspects of the attorney's duty of loyalty, corresponding to the expectations of the client. ${ }^{148}$ The court demonstrated the extent of the historical traditions supporting such an unenumerated obligation, quoting at length a judicial opinion dating back to $1889 .{ }^{149}$ The quotation, which eloquently and forcefully details the "obligation" of "fidelity to [the] client," concludes with the insistence that "I cannot tolerate for a moment, neither can the profession, neither can the community, any disloyalty on the part of a lawyer to his client. In all things he must be true to that trust, or, failing it, he must leave the profession."150

144. See supra notes $64-73$ and accompanying text.

145. Cardona v. Gen. Motors Corp., 942 F. Supp. $968,974-75$ (D.N.J. 1996).

146. Id at 975 .

147. Id

148. See id; see also Heringer v. Haskell, 536 N.W.2d 362, 366-67 (N.D. 1995) (finding that "[c]ertainly concerns about the public's perception of the legal profession, particularly as it relates to confidentiality of client information, bears some relevance when we examine and interpret the Rules" and deriding that interpreting the appearance of impropriety standard through such factors as "the layperson's view," "public confidence in the legal profession," and "the nature of private law practice in this state" as found in "the common experience in North Dakota law firms" is appropriate); cf. First Am. Carriers v. Kroger Co., 787 S.W.2d 669, 672 (Ark. 1990) (finding that Canon 9 "is included in ... 'moral and ethical considerations' that should guide lawyers, who have 'special responsibility for the quality of justice"').

149. Cardona, 942 F. Supp. at 975 (quoting United States v. Costen, 38 F. 24, 24 (C.C.D. Colo. 1889)).

150. Id. (quoting United States v. Costen, 38 F. 24, 24 (C.C.D. Colo. 1889)). 
Other courts have adopted an interpretive methodology for applying the appearance of impropriety standard based on an extension of the principles underlying enumerated ethics rules, thus echoing the interpretation of the constitutional protections of privacy and the biblical requirement to do the just and the good. ${ }^{152}$ Under such an approach, one court applying the appearance of impropriety standard found "no doubt that the spirit of the ethical norms adhered to in this district, if not the letter of the Rules of Professional Conduct themselves, precludes an attorney from acquiring, inadvertently or otherwise, confidential or privileged information about his adversary's litigation strategy."152 The court then cited a number of ethics rules, the letter of which perhaps did not enumerate the precise prohibition articulated by the court, but the spirit of which suggested such an unenumerated prohibition due to an appearance of impropriety. ${ }^{153}$ Another court in examining the standard, "to mark its precise contours ... looked to other provisions of the ABA Model Code for guidance." 154 Specifically, the court based its conclusions on a "read[ing]" of both Canon 4 and Canon 5, "together with" Canon 9. ${ }^{155}$

151. See supra notes $74-82$ and accompanying text.

152. MMR/Wallace Power \& Indus. v. Thames Associates, 764 F. Supp. 712,718 (D. Conn. 1991).

153. See id. at 718-19 (citing MOdel RULes OF Prof'L CONDUCt R. 1.6, R. 4.2, R. 8.4); id. at 719-23 (citing and relying on cases that applied appearance of impropriety and similar standards). The court concluded: "That the court has an obligation "to enforce the lawyer's duty to absolute fidelity and to guard against the danger of inadvertent use of confidential information' pertaining to his adversary's trial preparation and tactics is, upon review of the case law in this area, unmistakably clear." Id. at 719 (citations omitted).

154. Pantry Pride, Inc. v. Finley, Kumble, Wagner, Heine, Underberg \& Casey, 697 F.2d 524, 530 (3d Cir. 1982).

155. Id. at 530; see Model CODE OF Prof'L ResponsibILTTY Canon 4 (1981) ("A Lawyer Should Preserve the Confidences and Secrets of a Client."); id. Canon 5 ("A Lawyer Should Exercise Independent Professional Judgment on Behalf of a Client.").

At least one court has combined two interpretive methodologies, looking both to the historical function of lawyers and to the implications of other enumerated ethics rules for interpreting and applying the appearance of impropriety standard. See Arkansas v. Dean Foods Prods., 605 F.2d 380 (8th Cir. 1979). The court first observed that "[s]ociety has ordained and for centuries honored the privilege against disclosure, to reassure the people that their secrets were safe in the hands of their lawyers." $1 d$. at 385 . The court then explored the implications of this traditional function, noting that

[i]f the reputation and status of the legal profession, and more importantly the freedom and opportunity of the public to obtain adequate legal counseling, are to be preserved, a client must have every reason to expect that disclosures to "his" law firm will not be used against him by any member or associate lawyer in that firm.

Id. at 385-86. Finally, the court concluded that '[i]t is precisely to protect that 'expectation' of safety in disclosure that Canon 9's concern for the appearance of impropriety must be merged with Canon 4's injunction against disclosure of a client's secrets." Id. at 386. 
Finally, perhaps more than any other ethics provision, the appearance of impropriety standard articulates a level of generality similar to that of the Ninth Amendment and the biblical command to love one's neighbor, thus suggesting the applicability of a third interpretive methodology, one that provides an independent source for that which is otherwise unenumerated elsewhere. In fact, much of the criticism of the appearance of impropriety standard has specifically rejected its use as an independent basis for disqualification or discipline. $^{156}$

It is therefore significant that the United States Court of Appeals for the Ninth Circuit rejected the argument that "the [district] court erred in relying solely on Canon 9 to disqualify the law firms."157 The court declared that "[s]trong policy reasons support" the conclusion that "Canon 9 alone can be the basis for a disqualification motion." Perhaps the most notable of these considerations, in terms of its broader implications for understanding the nature of ethics codes, posits that "[i]f Canon 9 were not separately enforceable, it would be stripped of its meaning and significance. This suggests that it must be a sufficient ground for disqualification in itself."159 Thus, though apparently in the minority, ${ }^{160}$ the Ninth Circuit took seriously each of the provisions of the Code of Professional Responsibility, refusing to entertain the possibility that even a broad provision such as the appearance of impropriety standard might be devoid of independent meaning, interpretation, and application. ${ }^{161}$

156. See, e.g., Leber Assocs., LLC v. Entm't Group Fund, No. 00 Civ. 3759, 2001 WL 1568780 , at *7 (S.D.N.Y. Dec. 7, 2001) ("If plaintiff intends to suggest that disqualification is independently justified by [Canon 9], we reject that contention."); Bd. of Educ. v. Nyquist, 590 F.2d 1241, 1250 (2d Cir. 1979) (Mansfield, J. concurring) (stating "that an 'appearance of impropriety' is an insufficient ground, by itself, to justify a court's disqualification of an attorney ... absent a reasonable basis for believing that such an appearance may affect the outcome"); $i d$. at 1247-48 n.l (Mansfield, J. concurring) (citing a case in which "a combination of an attorney's 'appearance of impropriety' plus his violation of another disciplinary rule might have affected the outcome"); see also GiLLERS, supra note 41, at 359 (stating that "a few states retain the Code of Professional Responsibility and its Canon 9, [but adding] that doesn't mean that courts in those states will make judgments about conflicts based on the 'appearance' language alone").

157. In re Coordinated Pretrial Proceedings in Petroleum Prods. Antitrust Litig., 658 F.2d 1355, 1359-60 (9th Cir. 1981).

158. Id at 1360 .

159. Id.

160. See supra notes 34-41, 137-142, 156 and accompanying text.

161. The Kentucky Supreme Court made a similar observation:

Although the appearance of impropriety formula is vague and leads to uncertain results, it nonetheless serves the useful function of stressing that disqualification properly may be imposed to protect the reasonable expectations of 
The comparison to the Ninth Amendment is somewhat striking. Commentators have long noted the virtual "disappearance of the Ninth Amendment from the Supreme Court's constitutional discourse." fact, as one scholar recently documented:

Although a few Supreme Court justices have mentioned the amendment-usually to provide a kind of indirect thematic support for the assertion of an unenumerated right identified in another provision of the Constitution-no Supreme Court decision, and few federal appellate decisions, have relied on the Ninth Amendment for support. Indeed, federal courts that have discussed the Ninth Amendment have almost exclusively. held that it does not confer any substantive rights. ${ }^{163}$

former and present clients. The impropriety standard also promotes the public's confidence in the integrity of the legal profession. For these reasons, courts still retain the appearance of impropriety standard as an independent basis of assessment.

Lovell v. Winchester, 941 S.W.2d 466, 469 (Ky. 1997); cf. Sullivan County Reg'l Refuse Disposal Dist. v. Town of Acworth, 686 A.2d 755, 757 (N.H. 1996) ("The courts of this State are the primary regulators of attorney conduct. It would be inconsistent with this court's supervisory role to relegate the Rules of Professional Conduct to the status of guidelines, to be enforced only when the trial process may be sullied." (citations omitted)). In contrast, the New York high court observed:

We begin our analysis by noting that what is at issue is a disciplinary rule, not a statute. In interpreting statutes, which are the enactments of a coequal branch of government and an expression of the public policy of this State, we are of course bound to implement the will of the Legislature; statutes are to be applied as they are written or interpreted to effectuate the legislative intention. The disciplinary rules have a different provenance and purpose. Approved by the New York State Bar Association and then enacted by the Appellate Divisions, the Code of Professional Responsibility is essentially the legal profession's document of selfgovernance, embodying principles of ethical conduct for attorneys as well as rules for professional discipline. While unquestionably important, and respected by the courts, the code does not have the force of law.

That distinction is particularly significant when a disciplinary rule is invoked in litigation, which in addition to matters of professional conduct by attorneys, implicates the interests of nonlawyers. In such instances, we are not constrained to read the rules literally or effectuate the intent of the drafters, but look to the rules as guidelines to be applied with due regard for the broad range of interests at stake.

Niesig v. Team I, 558 N.E.2d 1030, 1032 (N.Y. 1990) (citations omitted).

162. See, e.g., Hon. William Wayne Justice, Recognizing the Ninth Amendment's Role in Constitutional Interpretation, 74 TEX. L. REv. 1241, 1243 (1996).

163. Mark C. Niles, Ninth Amendment Adjudication: An Alternative to Substantive

Due Process Analysis of Personal Autonomy Rights, 48 UCLA L. REv. 85, $89-90$ (2000)

(footnotes omitted). Another scholar also noted:

[T] he courts have ignored the Ninth Amendment altogether. They have treated it as though it does not envision judicial protection for unenumerated rights at all, a notion which has gained credence through the inertia of its neglect. Sub silentio, the courts have gradually instilled the idea that there is, in fact, no such thing as Ninth Amendment rights. 
This attitude toward the Ninth Amendment was perhaps most sharply captured in Judge Robert Bork's testimony during his Senate confirmation hearing. Drawing a famous analogy to an inkblot, Bork declared:

I do not think you can use the Ninth Amendment unless you know something of what it means. For example, if you had an amendment that says 'Congress shall make no' and then there is an inkblot, and you cannot read the rest of it, and that is the only copy you have, I do not think the court can make up what might be under the inkblot. ${ }^{164}$

At the start of an influential article on the Ninth Amendment, Professor Randy Barnett juxtaposes Bork's statement against the United States Supreme Court's landmark decision in Marbury $v$. Madison declaring: "It cannot be presumed that any clause in the constitution is intended to be without effect; and therefore such a construction is inadmissible, unless the words require it."165 Though ethics codes may not demand the same level of attention to textual detail as does the Unites States Constitution, the Ninth Circuit's insistence that the appearance of impropriety standard is deserving of independent authority echoes the Supreme Court's approach

Chase J. Sanders, Ninth Life: An Interpretive Theory of the Ninth Amendment, 69 IND. L.J. 759, 761 (1994).

164. The Bork Disinformers, WALL ST. J., Oct. 5, 1987, at 22, quoted in Barnett, supra note 52, at 1. Professor Mark Niles has depicted the "inkblot interpretation" as "almost certainly the dominant understanding, and consequently the overwhelming treatment, of the amendment by legal practitioner and judges." Niles, supra note 163, at 98; $c f$. Troxel v. Granville, 530 U.S. 57, 91 (2000) (Scalia, J., dissenting) (stating that "the Constitution's refusal to 'deny or disparage' other rights is far removed from affirming any one of them, and even further removed from authorizing judges to identify what they might be, and to enforce the judges' list against laws duly enacted by the people").

165. 5 U.S. (1 Cranch) 137, 174 (1803), quoted in Barnett, supra note 52, at 1. 
articulated in Marbury and applied by Justice Goldberg ${ }^{166}$ and many scholars to the Ninth Amendment. ${ }^{167}$

The notion of a similarly general and independent source of unenumerated principles in Jewish law is perhaps most powerfully expressed in the command to "love your neighbor as yourself."168 As explicated by Maimonides, the command to love one's neighbor serves as a wide-ranging source of interpersonal obligations beyond those enumerated in the biblical text, including the general obligation to protect the well-being of another person to the same degree as one would be concerned about one's own well-being. ${ }^{169}$ Specifically, he

166. See Griswold v. Connecticut, 381 U.S. 479, 491 (1965) (Goldberg, J., concurring) (stating that "[i]n interpreting the Constitution, 'real effect should be given to all the words it uses," and arguing that failure to recognize a constitutional right because it is not enumerated in the first eight amendments to the Constitution "is to ignore the Ninth Amendment and to give it no effect whatsoever").

To be precise, Justice Goldberg offered what one scholar has called a "rather equivocal reliance on the Ninth Amendment," rather than adopting the position that "the Ninth Amendment constitutes an independent source of rights protected from infringement by either the States or the Federal Government." Thomas B. McAffee, A Critical Guide to the Ninth Amendment, 69 TEMP. L. REv. 61, 61-62 n.7 (1996) (quoting Griswold, 381 U.S. at 492 (Goldberg, J., concurring)). Nevertheless the logic of Justice Goldberg's opinion would seem to support such a position. For an attempt to define and explain Justice Goldberg's approach, see McAffee, supra, at 62.

167. In the words of "the very first Ninth Amendment thinker," writing in "the first [article] devoted exclusively to the Ninth Amendment," the amendment "must be more than a mere net to catch fish in supposedly fishless water." Knowlton H. Kelsey, The Ninth Amendment of the Federal Constitution, 11 IND. L.J. 309, 323 \& n.7 (1936), quoted in Sanders, supra note 163, at 761-62; see also CHARLES L. BLACK, JR., DECISION ACCORDING TO LAW: THE 1979 HOLMES LECTURES 43 (1981), cited in Justice, supra note 162, at 1243-44 (exhibiting characteristic wit in stating: "I ... move that, having been proposed by the requisite majorities in Congress, and ratified by the requisite number of states, the Ninth Amendment to the Constitution of the United States at long last be adopted"). Professor Massey asserted:

Construing the $[\mathrm{N}]$ inth $[\mathrm{A}]$ mendment as a mere declaration of a constitutional truism, devoid of enforceable content, renders its substance nugatory and assigns to its framers an intention to engage in a purely moot exercise. This view is at odds with the contextual historical evidence and the specific, articulated concerns of its framers, and violates the premise of Marbury $v$. Madison that the Constitution contains judicially discoverable and enforceable principles.

Calvin R. Massey, Federalism and Fundamental Rights: The Ninth Amendment, 38 HASTINGS L.J. 305, 316-17 (1987); McAffee, supra note 166, at 67 ("To the modern reader, the Ninth Amendment seems quite plainly to recognize rights in addition to those secured by the text of Constitution and the Bill of Rights.").

168. Leviticus 19:18.

169. MAIMONIDES, supra note 73, Laws of De'oth 6:3; cf. 3 NACHMANIDES, supra note 55, at 292-94 (explicating Leviticus 19:18) (describing the obligation to hope for the success of others in all of life's realms, including those of wealth, honor, and knowledge). For an analysis of the view of Nachmanides, see YITZCHAK HUTNER, PACHAD YITZCHAK, SHEVUOTH 134-38 (5th ed. 1999). 
delineates a number of actions mandated by rabbinic authorities in connection with the biblical command to love others, including visiting the sick, comforting mourners, and participating in funerals and weddings. ${ }^{170}$ In short, Maimonides concludes, one should act toward others in the same manner in which one would wish to be treated by others. ${ }^{17}$

This approach to understanding the command to love one's neighbor may offer a final insight into interpretive methodologies that rely on broad rules to derive and identify unenumerated principles in ethics codes, the United States Constitution, and the Torah. Under Jewish legal theory, each verse in the Torah has significance and meaning. ${ }^{172}$ Thus, biblical interpretation, like constitutional interpretation, operates under a strong presumption against superfluity, rendering moot the possibility that the phrase "love your neighbor as yourself" is anything other than a legal imperative. ${ }^{173}$ Indeed, because this presumption "proceeds directly from the view of Torah as divine revelation,"174 it precludes application to the Torah of approaches such as Bork's inkblot theory of the Ninth Amendment ${ }^{175}$ or those of courts and scholars denying the value of the appearance of impropriety standard. Though not divine in origin, if they are to be taken seriously, ethics codes and the Constitution deserve and demand a similar respect for their textual integrity through the interpretation of broad provisions as a source of unenumerated principles.

170. MAIMONIDES, supra note 73, Laws of Mourning 14:1.

171. Id: of. 3 NACHMANIDES, supra note 55, at 293 (explicating Leviticus 19:18) (concluding that a person's love for the success of others should be without bounds, as is the hope one has for one's own success).

172. Modern scholars have offered the term "omnisignificance" to describe "the basic assumption ... that ... [n]othing in the Bible ... ought to be explained as the product of chance, or, for that matter, as an emphatic or rhetorical form, or anything similar." JAMES Kugel, The Idea of Biblical POETRY: Parallelism and Its History 104 (1981), cited in Yaakov Elman, "It Is No Empty Thing": Nahmanides and the Search for Omnisignificance, 4 TORAH U'MADDAH J. 1 (Jacob J. Schacter ed., 1993).

Professor Elman finds an analog to this observation in the Talmudic statement that the Torah "[i]s not an empty thing for you, it is your very life, and if [it appears] devoid [of moral or halakhic meaning], it is you [who have not worked out its moral or legal significance]." Elman, supra, at 1-2. (alterations in original) (quoting JERUSALEM TALMUD, Kethuvoth 8:11 (explicating Deuteronomy 32:47)).

173. In fact, as Professor Elman develops at length, biblical interpretation attributes omnisignificance not only to legal precepts but to biblical narrative as well. See generally Elman, supra note 172; Levine, supra note 70.

174. Elman, supra note 172 , at 4.

175. See supra note 164 and accompanying text. 


\section{CONCLUSION}

The increasingly legislative form of ethics regulations has produced a statutory structure that, like other legislation, requires careful and close judicial analysis and interpretation. In fact, Professor Monroe Freedman has emphasized the "extremely effective means [ethics codes] provide to learn how to draft and analyze statutes.",176 As Professor Freedman observes, "[s]ome of the ethical rules deal with specific, limited issues, like forbidding a lawyer to commingle funds or to engage in ex parte communications with a judge."'n7 Yet he also notes that "[o]thers are the loosest of canons, forbidding any conduct that gives the 'appearance of impropriety' or that is 'prejudicial to the administration of justice." ${ }^{\text {"178 }}$ It is the latter category that has prompted many scholars and some courts to question the legislative legitimacy of segments of ethics codes, a skepticism that has been expressed in the practical and theoretical rejection by these critics of the applicability of broad ethics provisions.

Indeed, in the areas of both constitutional law and legal ethics, the practice of deriving unenumerated principles through the interpretation and application of broad provisions has been a somewhat precarious one. Perhaps by its nature, such a hermeneutic framework is vulnerable to the criticism that it is improperly vague, relying on interpretive methodologies that lack the precision generally expected of both legislative schemes and their interpretation.

Nevertheless, to courts and scholars advocating and engaging in such methodologies, the nature of both ethics codes and the United States Constitution, like the nature of the Torah in Jewish legal theory, necessitates the articulation of broad rules to address situations and considerations, beyond those enumerated, that will inevitably arise in the future. Thus, it is incumbent upon legal authorities in each of these areas of law to construct a conceptual framework through which such unenumerated principles may be identified and applied.

Though not without encountering occasional criticism and difficulty, legal authorities have relied on a number of interpretive methodologies that have proved largely successful in the pursuit of deriving and identifying unenumerated constitutional rights and unenumerated biblical obligations. Taking the legislative forms of the United States Constitution and the Torah seriously, these authorities

176. FREEDMAN, supra note 108 , at 1.

177. Id.

178. Id. 
have thus demonstrated the utility of a legislative structure consisting of both specifically enumerated rules and broad provisions. If ethics codes are likewise to be taken seriously, scholars and courts should reexamine their criticism of broad ethics provisions and carefully consider adopting interpretive frameworks that have proved so valuable in other areas of law but have remained largely underappreciated in ethics interpretation. 